\title{
A Competência do Tribunal de Justiça das Comunidades Européias para Fiscalizar a Compatibilidade do Direito dos Estados-Membros Com a Convenção Européia dos Direitos do Homem* Um Estudo de Direito Constitucional
}

NUNO PIÇARRA

Assessor no Tribunal de Primeira Instância das Comunidades Européias. Docente no Instituto de Estudos Europeus da Universidade do Sarre, Alemanha

\section{I - APRESENTAÇ̃̃O DO TEMA}

1. Em matéria de direitos fundamentais, os desenvolvimentos mais recentes a assinalar na jurisprudência do Tribunal de Justiça das Comunidades Européias (a seguir designado por ") prendem-se com a assunção, por parte deste órgão jurisdicional, da competência para fiscalizar, em cooperação com os tribunais nacionais, a compatibilidade dos atos normativos dos Estados-Membros com o elenco de direitos fundamentais que, tal como resultam, designadamente, da Convenção Européia dos Direitos do Homem, assinada em Roma em 4 de Novembro de 1950 (a seguir designada por "CEDH"), fazem parte integrante da ordem juridica comunitária ${ }^{1}$

Noutra perspectiva, trata-se de determinar a medida em que os particulares podem obter do TJ proteção contra os atos legislativos e regulamentares alegadamente lesivos de tais direitos, imputáveis não à Comunidade Européia mas aos Estados-Membros. E isto sem prejuizo da proteção que eventualmente possam obter, contra os mesmos atos, por parte dos respectivos tribunais constitucionais nacionais e do Tribunal Europeu dos Direitos do Homem.

*Agradeço ao Dr. José Luís Ramos, Assistente da Faculdade de Direito da Universidade de Lisboa, de cuja leitura atenta e critica este texto beneficiou substancialmente. A minha responsabilidade é, porém, exclusiva no que respeita às deficiências e eventuais erros.
II - PRINCIPAIS CARACTERÍSTICAS DA TUTELA JURISDICIONAL DOS DIREITOS FUNDAMENTAIS NA ORDEM JURÍDICA COMUNITÁRIA

A - A Integração Progressiva, por Via Pretoriana, de um Catálogo de Direitos Fundamentais no Ordenamento Comunitário

1. Ao invés das constituições dos EstadosMembros, o Tratado que institui a Comunidade Econômica Européia, assinado em Roma em 25 de Março de 1957 (a seguir designado por "Tratado") ${ }^{3}$, não contém uma declaração de direitos fundamentais. Dado que os trabalhos preparatórios do Tratado nunca foram tornados pủblcos, não se conhecem exatamente as razões de uma tal ausência. Ela è freqüentemente explicada pelo fato de os autores do Tratado, inspirados pelo modelo de uma organização internacional, terem pretendido criar uma Comunidade de indole econômica e não politica, cujos sujeitos juridicos eram sobretudo encarados na sua qualidade de agentes de uma economia de mercado. Supunha-se que, com tais características, a nova Comunidade, ao invés de um Estado, não seria em principio suscetivel de afetar os direitos fundamentais da pessoa humana.

Esta não é, no entanto, a explicação mais plausivel. Tendo em conta nomeadamente poderes de regulamentação da iniciativa privada de que a Comunidade Econômica Européia ficava a dispor, não poderia ter parecido aos ficava a dispor, não poderia ter parecido aos
autores do Tratado de todo em todo despicienautores do Tratado de todo em todo despicien-
da a questão da garantia, no âmbito de aplicação deste, de uma série de direitos e liberdades da pessoa humana, tradicionalmente encarados como limites aos poderes de autoridade do Estado e onde se incluem, a titulo exemplificativo, o direito à propriedade privada, a garantia de acesso aos tribunais, o direito de audição e de fesa, os principios nulla poena sine lege, no bis in idem, mas também o direito à reserva da intimidade da vida privada e familiar, à inviolabilidade do domicilio e da correspondência, liberdade de expressão e informação, etc.

Em 1957, porém a proteção dos direitos fundamentais contra os atos normativos ou individuais dos órgãos da Comunidade deve ter sido considerada pelos autores do Tratado como incumbência das várias ordens juridicas nacionais. Com 0 exemplo norte-americano decerto no horizonte, ter-se-á temido que a atribuição, aos órgãos centrais da Comunidade, da competência para aplicar um catálogo próprio de direitos fundamentais tivesse por consequêencia a expansão progressiva dos poderes desses órgãos em detrimento dos Estados-Membros, dada a natureza indeterminada e por conseguinte carecida de amplo preenchimento normativo de um recida de amplo preenchimento normativo de um tal catálogo. A omissão relativa aos direitos fundamentais por parte dos autores do Tratado terá sido, afinal, deliberada 4

2. Importa, em todo o caso, precisar que 0 fato de o Tratado não conter um catálogo de direitos fundamentais próprio, elaborado em tertuições dos Estados-Membros, não implica que ele não inclua disposições de grande relevância nesta materia, suscetiveis de concretização jurisdicional. Pense-se, em primeiro lugar, no artigo $164^{\circ}$ que, ao incumbir o TJ da missão de "assegurar o respeito do direito na interpretação e aplicação do presente tratado", aponta para a integraça em tal conceito de direito de componente de direitos fundamentais a proteger autonomamente no ordenamento comunitário. Pense-se, em segundo lugar, no principio de proibição de discriminações em razão da nacionalidade (artigo $7^{\circ}$ ) ou entre produtores e consumidores de produtos agricolas (artigo 40). Pense-se, ainda, no artigo 119 que visa a igualdade de remuneração entre homens e mulheres $^{5}$.

Podem evocar-se, por outro lado, os artigos 48,52 e 59 que, proibindo discriminações em razão da nacionalidade nos setores do trabalho assalariado, do estabelecimento e da prestação de servicos, mas visando igualmente a eliminana discriminatórios nesses setores, são equiparáveis, como certa doutrina cedo salientou, a verdadeiros direitos fundamentais, tal como se acham consagrados nas constituiçōes dos Estados-Membros: direito de deslocação e de emigração, liberdade de escolha de profissão, liberdade de comércio e de indústria ${ }^{6}$.

3. Seja como for, a primeira abordagem, por parte do TJ, da questão da tutela dos direitos fundamentais, no acórdão de 4 de Fevereiro de 1959, Storck/Alta Autoridade 7 , proferido no âmbito do Tratado que institui a Comunidade Européia do Carvão e do Aço, não pode deixar de considerar-se claudicante. Chamado a deci- 
dir se um determinado ato imperativo da Alta Autoridade violava o direito fundamental do respectivo destinatário ao livre desenvolvimento da personalidade, bem como o direito fundamental à livre escolha de profissão, tal como se acham corantidos, respectivamente, pelos artigos $2^{\circ}$ garantidos, respectivamente, pelos artigos $2^{-}$ 12 da Constituição alemã, o TJ limitou-se a resgarantir o respeito do direito na interpretação $e$ na aplicação do Tratado e dos regulamentos de execução deste, não lhe competia, em principio, pronunciar-se sobre as regras de direito interno dos Estados-Membros nem, portanto, sobre

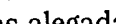
as alegadas infraçōes a tais regras por parte dos atos adotados pelos orgãos da Comunidade. $\mathrm{E}$ bem possivel que o $\mathrm{TJ}$ tenha seguido uma
al orientação movido pelo receio de que, na falta, ao tempo, de um principio de primazia do direito comunitário nas ordens juridicas nacionais, a invocação sistemática das normas constitucionais ai vigentes em matéria de direitos fundamentais contra os atos juridicos de fonte comunitária pudesse, em última análise, paralisar a ação da Comunidade. No entanto, havendo que partir do pressuposto de que o $\mathrm{TJ}$ não pode ter pretendido afirmar que os atos pra ticados pelos órgãos da Comunidade estavam dispensados do respeito dos direitos fundamentais, torna-se logicamente impossivel não interpretar o acórdão Storck no sentido de que, para pretar o acórdão Storck no sentido de que, para
o TJ, a missão de garantir o respeito de tais dio TJ, a missão de garantir o respeito de tais di-
reitos perante os atos da Comunidade cabia afireitos perante os atos da Comunidade cabia afinal aos tribunais nacionais, de acordo com os Tertium non datur ${ }^{8}$.

4. Se, apesar do que precede, a ordem juridica comunitária foi integrando, progressivamente, um catálogo de direitos fundamentais tal acabou por dever-se em medida determinante, à própria ação do TJ, ultrapassada a primeira fase da sua jurisprudencia. Com efeito, foi 0 TJ que, numa jurisprudência iniciada com acórdão de 12 de Novembro de 1969, Stauder/ Cidade de Ulm?, "descobriu” progressivamente Cidade de Ulm "descobru" progressivamente no Tratado um elenco não escrito de direito fundamentais idêntico aos que figuram nas constituiçōes dos Estados-Membros ${ }^{10}$ e destinado a servir de parâmetro de validade, desde logo, aos atos juridicos adotados pelo Conselho e pela Comissão da Comunidade Européia Com isto mesmo, de resto, o TJ contribuiu decisivamente para a constitucionalização do Tratado, ou seja, conversão deste na "carta constitucional de uma Comunidade de Direito"11.

Os princípios pretorianamente fixados em matéria de proteção dos direitos fundamentais no ordenamento comunitário podem enunciarse nos seguintes termos: os direitos fundamen(uncipios gerais do direito comunitário cuja observância garantida pelo TJ; a proteção desses direitos deve ser garantida tendo em conta a estrutura os objetivos da Comunidade; tal proteção inspira-se nas tradições constitucionais comuns aos Estados-Membros, bem como nas indicações fornecidas pelos instrumentos internacionais mem em que os Estados-Membros cooperaram ou a que aderiram, com especial destaque para a $\mathrm{CEDH}$ não podem, por conseguinte, ser admitidas na Comunidade medidas incompativeis com os direitos fundamentais assim reconhecidos e garantidos ${ }^{12}$.

Por outro lado, o TJ cedo deixou claro que a questão das eventuais violaçōes dos direitos fundamentais por atos praticados pelos órgãos da Comunidade só poderia ser apreciada no quadro do próprio direito comunitário. Segundo o $T J$, o recurso a critérios de validade decorrentes da ordem constitucional de um determinado Estado-Membro poria em causa a unidade ma作 cado perante alegadas violaçōes, por parte de atos juridico-comunitários, de direitos fundamentais, tal como os enuncia a constituição de um Estado-Membro, ou de principios de uma determinada ordem constitucional nacional, TJ deverá apenas "analisar se não terá sido violada qualquer garantia análoga, inerente ao direito comunitário"13. Isto significa que o controle da compatibilidade dos atos juridico-comunitários com os direitos fundamentais exercido pelo $\mathrm{TJ}$ traduz-se essencialmente numa escolha da better law, ou seja, da solução mais adequada às exigências proprias do ordenamento munitário, e não na aplicaça munitario, e na na aplicaca automatica ao caso concreto do ou dos direltos fundamentais que a ordem constitucional de um determinado Estado-Membro supostamente proteja com a máxima intensidade ${ }^{14}$

Refira-se, por fim, para se ter uma idéia precisa do significado da ação do TJ no dominio em análise, que 0 próprio Tratado da União Européia, em alternativa à inclusão expressa de um catálogo de direitos fundamentais, limitouse a consagrar, no essencial, as formulas jurisprudenciais acabadas de citar. Assim, segundo o artigo $\mathrm{F}, \mathrm{n}^{\circ} 2$ 2, "a União respeitará os direitos fundamentais tal como os garante a Convenção Européia de Salvaguarda dos Direitos do Homem e das Liberdades Fundamentais, assinada mem e das Liberdades Fundamentais, assinada em Roma em 4 de Novembro de 1950, e tal como resultam das tradições constitucionais comuns aos Estados-Membros, enquanto principios gerais do direito comunitário". Só não deixa de parecer paradoxal que 0 artigo L exclua da com$\mathrm{n}^{0} 2^{15}$.

5. Após ter examinado o sentido e o alcance da evolução jurisprudencial relativa à tutela dos direitos fundamentais no ordenamento comunitário, importa recordar as razōes que levaram o TJ a mudar tão significativamente de orientação, do acórdão Storck para o acórdão Stauder. supracitados. Embora atuando em profunda interação, podem-se destrinçar duas ordens de razões, de mais a mais, de natureza potencialmente conflitual.

A primeira liga-se com a caracterização progressiva, por ação do TJ, do direito comunitário como um corpo normativo direta e uniformemente aplicável e, por conseguinte, dotado de primado sobre quaisquer normas nacionais con-
trárias, no conjunto formado pelas ordens juritrárias, no conjunto formado pelas ordens juri-
dicas dos vários Estados-Membros, a partir do dicas dos vários Estados-Membros, a partir do impulso inicial dado pelos acórdãos de 5 de Fevereiro de 1963, Van Gend \& Loos/Administração Fiscall ${ }^{16}$, e de 15 de Julho de 1964 , Costa/ substantiva do direito comunitário corresponde, antes de mais, a uma imposição do princide, antes de mais, a uma imposid
pio de igualdade perante a lei.

A segunda ordem de razões prende-se com o fato de, à data da instituição da Comunidade Européia, os tribunais comuns da Alemanha e da Itália serem competentes, mediante "supervisão" de um tribunal constitucional, para fiscalizar a compatibilidade das normas aplicáveis aos litigios que thes são submetidos a julgamento, nomeadamente com o catálogo de direitos fundamentais consagrado na respectiva constituição. A priori, uma tal competência era extensivel a quaisquer normas aplicáveis no territó- rio respectivo, independentemente da sua origem.

Nestas condiçōes, a aplicação uniforme do direito comunitário (primário e secundário) no conjunto formado pelos ordenamentos jurídicos de todos os Estados-Membros só ficaria garantida mediante o preenchimento de dois requisitos essenciais. Por um lado, era indispensável que, na falta de uma norma reconhecidamente superior que lho impusesse, os competentes ôrgãos dos dois Estados-Membros referidos se abstivessem de desaplicar ou invalidar, não só as disposições do Tratado, como também os atos de fonte comunitária adotados em sua execução, que reputassem contrários aos direitos fundamentais consagrados pelas respectivas constituições. Por outro lado, tornava-se necessário que o TJ, "em contrapartida" dessa abstenção, mas sobretudo em nome da aplicação uniforme do direito comunitário, passasse ele próprio considerar-se exclusivamente competente para invalidar atos de fonte comunitária com fundamento em violação de direitos fundamentais.

Percebe-se, nesta ótica, que a consagração do principio da tutela dos direitos fundamentais na ordem juridica comunitária e a elaboração progressiva de um catálogo não escrito desses direitos constituem as técnicas a que o $\mathrm{TJ}$ teve que recorrer para aquele efeito ${ }^{18}$.

A profunda interação entre os fatores acabados de referir torna-se mais clara tendo em conta o enquadramento processual em que teve lugar. Trata-se do reenvio prejudicial, tal como o configura o artigo 177 do Tratado. Ao abrigo desta disposição se estabeleceu, de fato, a sôlida cooperação entre o TJ e os orgãos jurisdicionais nacionais, seus interlocutores incontornáveis, que esteve na origem da jurisprudência comunitária em matéria de direitos fundamentais. Adiante-se, desde já, que é exatamente no mesmo enquadramento processual que se tem operado a extensão da competência do TJ sobre que incide 0 presente estudo.

B - O Artigo 177 do Tratado e a Cooperação Entre o TJ e os Tribunais Nacionais no Âmbito da Proteção dos Direitos

Fundamentais

1. Os tribunais nacionais são os órgãos jurisdicionais comuns - a primeira linha, por 
assim dizer - de aplicação do corpus normativo que integra a Comunidade. No quadro de um sistema pautado por uma profunda descentralização quer administrativa quer jurisdicional, o TJ tem fundamentalmente por missão garantir a aplicação uniforme, pelos tribunais nacionais, do direito comunitário. Isto implica, pelo menos, a sua última instância não só para interpretar o Tratado e os atos adotados pelos órgãos da Comunidade, mas também para verificar a validade destes atos à face do Tratado e, mais genericamente, do bloco de legalidade comunitäria.

Nestas condições, compreende-se que os principios relativos à proteção jurisdicional dos direitos fundamentais, bem como o elenco destes, tenham sido, no essencial, estabelecidos pelo $\mathrm{TJ}$, não no quadro do recurso direto de anulação nos termos do artigo 173 do Tratado ${ }^{19}$, mas sim no do artigo 177 - "pedra angular" do sistema jurisdicional comunitário - em resposta a questōes prejudiciais de interpretação e de validade de normas de fone los tribunais dos Estados-Membros com um sistema de controle jurisdicional de constitucionalidade. Tais questōes versavam, como é öbvio, sobre a compatibilidade dessas normas com a tutela efetiva de determinados direitos fundamentais ${ }^{20}$

Com efeito, dos leading cases na matéria, só 0 acórdão Nold foi proferido no quadro do artigo 173. Todos os outros (Stauder, Internationale 173. Todos os outros (Stauder, Internationale questōes prejudiciais de validade e de interpretação de determinadas normas constantes de diplomas aprovados pelo Conselho ou pela Comissão, pertinentes para a solução de litígios pendentes em tribunais alemães.

2. Como já se referiu, não podia ter-se por excluida a priori a possibilidade de os tribunais nacionais dotados de uma competência genérica de controle da constitucionalidade submeterem ao respectivo tribunal constitucional a questão da compatibilidade da norma de direito comunitario aplicave a litigio concreto com determinados direitos fundamentais, e isto mes mo após o $\mathrm{TJ}$ se ter pronunciado pela validade
da mesma à face do ordenamento comunitário da mesma à face do ordenamento comunitário nos termos do artigo 177. Foi, de resto, em tais circunstâncias que se fez sentir a influência de cisiva dos tribunais constitucionais alemão e ita- liano para a configuração do principio do respeito dos direitos fundamentais no ordenamento comunitário.

Com efeito, o acórdão de 29 de Maio de 197421, em que o Bundesverfassungsgerich definiu a sua competência para fiscalizar os atos da Comunidade, teve origem no acórdão do $T$. Ia Comationale Handelsgesellschaft, supracitado. $\mathrm{Na}$ seqüência deste ültimo acórdão - que não considerou inválido, à luz dos principios gerais do direito comunitário, o regulamento em matéria de política agricola comum concretamente aplicável - o mesmo tribunal que submetera ao $\mathrm{TJ}$ a questão prejudicial da validade de ta regulamento, submeteu ao Bundesverfassur gericht a questão da constitucionalidade do mesmo por referência, designadamente, ao direito fundamental de propriedade privada, tal como se acha expressamente consagrado pelo artigo 14 da Constituição alemã.

A evolução da jurisprudência do Bundesverfassungsgericht na matéria pode sintetizar-se da seguinte forma: afirmação, no supracitado acórdão, da competência para verificar a inconstitucionalidade de um regulamento comunitário, enquanto a ordem juridica comunitária não estivesse dotada de um catálogo de direitos fundamentais de origem parlamentar e equiparáve ao catálogo de direitos fundamentais constante da Constituicão alemã: renuncia generica ao exercício dessa competência enquanto a Comunidade e, em especial, a jurisprudência do $T J$ garantirem uma proteção eficaz dos direitos fundamentais perante os poderes de autoridade exercidos pelos respectivos órgãos, equiparável no essencial à que é assegurada pela Constituição alemä22. limitação progressiva dessa renúncia, ressalvando, num primeiro momento, a competência para fiscalizar plenamente a constitucionalidade das normas internas adotadas em execução de diretivas comunitárias (sem prejuizo do controle exercido pelo $\mathrm{TJ}$ sobre as diretivas em si mesmas ${ }^{23}$ ) e declarando, posteriormente, que a sua competência relativa à proteçāo dos direitos fundamentais não abrange apenas os atos praticados pelos órgãos do Estado alemão 24

A Corte Constituzionale italiana, por seu lado, tampouco deixou de se considerar competente para, em casos-limite, fazer prevalecer os direitos fundamentais constitucionalmente consagra- dos sobre o direito comunitário ${ }^{25}$. Recentemente, foi chamada a pronunciar-se sobre a compatibilidade com a constituição italiana do arti-
go 174 , segundo parágrafo, do Tratado que, na go 174 , segundo parágrafo, do Tratado que, na ral dos efeitos de uma declaração de invalidade de um regulamento comunitário proferida nos termos do artigo 177, de forma a nem sequer azer beneficiar dessa declaração as partes no processo principal em que se suscitou a respectiva questão prejudicial de validade. A Corte Constituzionale, num lapidar "acórdão admoestatório"26, tendo embora declarado o recurso inadmissivel, não deixou de aproveitar o ensejo para considerar a interpretação dada pelo TJ do artigo 174 como incompativel com o direito fundamental de acesso aos tribunais para a tutela efetiva dos direitos e interesses legitimos dos particulares, tal como o consagra a constituição italiana.

3. A "competência limitada" que expressamente se reservam, nos termos acabados de examinar, os dois tribunais constitucionais pode, à primeira vista, parecer objetivamente perigosa para a autonomia e unidade da ordem juridica comunitária. No entanto, tal atitude revela, sobretudo, a vontade compreensivel dos juizes constitucionais de influenciar a definição dos principios comunitários em matéria de proteção dos direilos fundamentais "vigiando" concretamente a justeza da ação do TJ a esse respeito.

No fundo, estes tribunais constitucionais põem como condição para "renunciarem" ao exercicio da competência que consideram ter para o controle de constitucionalidade de normas comunitárias, que o $\mathrm{TJ}$ aplique a essas normas um parâmetro de validade substancialmente idêntico ao vigente nos respectivos ordenamentos constitucionais ${ }^{27}$. Esta cooperação sui mentos constitucionais ${ }^{27}$. Esta cooperação sul generis tem trazido, apesar de tudo, um impor-
tante contributo para o aperfeiçoamento do sistema comunitário de proteção dos direitos fundamentais, não sendo, de resto, de excluir, por esta via novos desenvolvimentos da jurisprudência do $\mathrm{TJ}$ em matéria tão essencial.

\section{III - EXTENSÃO E LIMITES DA \\ COMPETÊNCIA DO TJ PARA FISCALIZAR A COMPATIBILIDADE DO DIREITO NACIONAL COM A CONVENÇÃO EUROPÉIA DOS DIREITOS DO HOMEM}

A - Enquadramento Orgânico e Processual

1. 0 que fica dito permite identificar o quadro orgânico e processual dentro do qual o $\mathrm{TJ}$ tem sido chamado a apreciar a compatibilidade de atos legislativos e regulamentares dos Estados-Membros com a CEDH. O TJ fá-lo agora exclusivamente no quadro do artigo 177, em resposta a questões prejudiciais de interpretacão do direito comunitário remetidas pelos tribunais nacionais. A via do artigo 173, já limitadamente utilizada para efeitos do controle da compatibilidade dos atos da Comunidade com a $\mathrm{CEDH}$, fica de todo em todo excluida quando estão em causa atos dos Estados-Membros.

Perguntar-se-á então em que termos precisos fiscaliza o TJ, à luz da CEDH, os atos dos Estados-Membros, sendo que o faz no âmbito de um processo originariamente concebido para garantir a interpretaçāo e aplicação uniformes do direito comunitário em todo o espaço juridico da Comunidade

2. A resposta decorre da transformação sofrida pelo processo do artigo 177 , em resultado da sua aplicação prática. A este respeito convém lembrar, antes de mais, que o direito comunitário coexiste com o direito nacional nos mais diversos dominios materiais. Isto levanta freqüentemente questões de compatibilidade entre ambos ou, o que é o mesmo, questões de aplicabilidade do direito nacional, tendo em conta 0 princípio do primado do direito comunitário. Não assim, que os tribunais nacionais . artigo 177 para questionar o TJ acerca do caráter eventualmente contrário ao bloco de legalidade comunitária das disposições de direito nacional pertinentes para a solução dos litigios que lhes são submetidos. 
Compreende-se igualmente que, em resposta a tais questōes, o TJ não se limite a interpretar, sem mais, o direito comunitário. Em vez disso, entra no âmago do litigio objeto do processo principal, tomando, no entanto, a precaução de o tornar abstrato, ou seja, de o apresentar como um conflito entre direito comunitário e uma hipotética disposição idêntica à que está em causa perante o tribunal nacional. Na prática, isto significa que o $\mathrm{TJ}$, instado pelos tribunais nacionais, passou a deci aplicabilidade jurisdicional do direito nacional. Os tribunais nacionais ficam, por conseguinte, vinculados, na maior parte dos casos, a desaplicar automaticamente a norma nacional julgada pelo TJ contrária ao direito comunitário. Nesta medida, a competência exercida pelo TJ, nos termos do artigo 177, tornou-se progressivamente equiparável à de um verdadeiro tribunal constitucional, embora não inclua o poder de anular formalmente as disposiçōes de direito nacional que repute contrárias ao direito comunitário ${ }^{28}$.

Assim se aplica que o $\mathrm{TJ}$ tenha enunciado a sua competência para fiscalizar a compatibilidade do direito nacional com ao CEDH nos seguintes termos.

"(...) Desde que uma regulamentação nacional entre no âmbito de aplicação do direito comunitário, o Tribunal de Justiça, chamado a decidir a titulo prejudicial, deve fornecer todos os elementos de interpretação necessários à apreciação, pelo órgão jurisdicional nacional, da conformidade desta regulamentação com os direitos fundamentais cujo respeito o Tribunal garante, tal como resulrespeito o Tribunal garante, tal como resul-
tam, em especial, da Convenção Européia dos tam, em especial, da Convenção Européia do
Direitos do Homem"29.

Importa agora examinar em que casos considera o TJ que uma regulamentação nacional entra no âmbito de aplicação do direito comunitário.

\section{B - o Acórdão Cinéthèque e a}

Contraposição Entre "Âmbito Próprio do

Direito Comunitário" e "Âmbito da Competência do Legislador Nacional". Crítica

1. O TJ abordou pela primeira vez o tema da sua competência especifica para apreciar um regulamentação nacional do ponto de vista da compatibilidade com a CEDH no acórdão de 11 de Julho de 1985, Cinéthèque/Fédération nationale des cinémas français ${ }^{30}$, proferido no quadro de um processo prejudicial desencadeado por um tribunal francês. Estavam em causa as disposiçōes do artigo 89 da lei francesa de 29 de Julho de 1982, regulamentadas por decreto de 4 de Janeiro de 1983. Tais disposiçóes deo periodo de um ano nenhuma obra cinematográfica explorada em salas de espetáculo poderia ser objeto de exploração simultânea designadamente sob a forma de videocassettes. Para além da questão de saber se estas disposições eram compativeis com as disposições do Tratado relativas à livre circulação de mercadorias e à livre prestacão de serviços, o tribunal nacional suscitou também a questão da compatibilidade com 0 artigo 10 da CEDH, que consagra a liberdade de expres-

O TJ começou por examinar as disposições de direito nacional em questão à face do artigo 30 do Tratado, tendo concluido por uma relacão de compatibilidade entre ambas. Seguidamente, a propósito do controle da compatibilidade de tais disposições com 0 artigo $10 \mathrm{da}$ $\mathrm{CEDH}$, o TJ declarou que:

se é verdade que incumbe ao Tribunal de Justiça garantir o respeito pelos direitos fundamentais no âmbito próprio do direito comunitário já não lhe cabe, porèm, examinar a compatibilidade, com a Convenção Européia, de uma lei nacional que se situa, como no caso concreto, num âmbito da competência do legislador nacional"31.

À primeira vista, não ficava excluido que, com esta solução, o TJ pretendesse acolher a "tese ortodoxa" segundo a qual o catálogo comunitário não escrito de direitos fundamentas se desaos atos adotados pelos órgãos da Comunidade, no exercicio das suas funções legislativa e administrativa, com exclusão, portanto, dos atos legislativos dos Estados-Membros, quaisquer que fossem. Estes apenas ficariam sujeitos ao eventual controle decorrente da aplicação de um parâmetro constitucional nacional ${ }^{32}$

Nas conclusões apresentadas no processo Cinéthèque, o advogado-geral considerou, ao invés, que, uma vez que se tratava de verificar se as referidas disposições legislativas nacionais, apesar de potencialmente restritivas da livre circulação de mercadorias, eram ainda assim compativeis com 0 artigo 30 do Tratado por se justificarem como "exigências à luz da $\mathrm{CEDH}^{33}$. Com esta tese, 0 advogado-geral prenunciava o essencial das criticas que viriam a ser dirigidas ao acórdão Cinéthèque e especificamente à sua interpretação restritiva de "âmbito de aplicação do direito comunitário" para efeitos da delimitação da competência fiscalizadora do TJ em tação da

2. As criticas ao acórdão Cinéthèque podem resumir-se nos seguintes termos: este acórdão excluiu incoerentemente do "âmbito de aplicação do direito comunitário" um tipo de casos que nele não pode deixar de se situar o que, alem do mais, representou uma involução em relação à jurisprudência anterior.

Como acaba de ver-se, o caso concreto situava-se no âmbito da chamada "integração negativa", ou seja, aquela que consistem em implementar as "liberdades fundamentais" previstas pelo Tratado. Mais concretamente, prendia-se com a competência dos Estados-Membros para, ao abrigo do próprio direito comunitário, introduzirem derrogaçōes a tais liberdades.

$\dot{E}$ sabido que as liberdades fundamentais em questão (liberdade de circulação de mercadorias, prevista pelo artigo 30 e segs; liberdade de circulação de trabalhadores, prevista pelo artigo 48 e segs; liberdade de estabelecimento, consagrada no artigo 52 e segs; liberdade de prestação de serviços, consagrada no artigo $59 \mathrm{e}$ segs.) decorrem diretamente do Tratado e das disposições comunitárias adotadas em sua execução. 0 exato conteúdo de tais liberdades, porém, só se determina tendo em conta dois tipos de disposições legislativas e regulamentares nacionais: por um lado, aquelas que, ao abrigo dos artigos $36,48, n^{\circ} 3,56$ e 66 do Tratado, estabeleçam limitaçōes ou derrogaçōes às liberdades comunitárias fundamentais, justificadas por razōes de ordem pública, de segurança pública e de saúde pública ${ }^{34}$; por outro lado, as disposiçōes que correspondam a exigências imperativas de interesse geral, não expressamente enumeradas nas cláusulas derrogatórias acabadas de mencionar, mas igualmente suscetiveis de permitir que os Estados-Membros adotem medidas que, de outro modo, seriam incompati- veis com o direito comunitário por constituirem entraves a tais liberdades ${ }^{35}$.

Ora, tais disposiçōes de direito nacional, contrariando as proibições dirigidas aos EstadosMembros nos termos dos artigos $30,48,52$ ou 59 do Tratado, só não serão contrárias à legalidade comunitária se, comprovadamente, conslituirem uma derrogação permitida pelos artigos $36,48, n^{\circ} 3,56$ ou 66 , ou se justificarem por "razōes imperativas de interesse geral". A definição daquilo que constitui uma violação das liberdades fundamentais consagradas pelo Tratado, assim como do que constitui uma derrogação licita a tais liberdades, não pode deixar de ser material e jurisdicionalmente uma quesão de direito comunitário. Cabe naturalmente o TJ definir o âmbito e o alcance de tais derrogações, sem perder de vista a ampla margem de discricionariedade de que os Estados-Membros dispōem nessa matéria ${ }^{36}$.

Tendo em conta que a lei nacional em causa no processo Cinéthèque produzia efeitos potencialmente restritivos das trocas intracomunitárias de mercadorias, só se justificando perante o artigo 30 se pudesse ser considerada como "exigência imperativa de interesse geral" - questão a decidir pelo $\mathrm{TJ}$ em colaboração com o tribunal a quo -, não se descortinam, à primeira vista, as razões que terão levado o juiz comunitário a considerar que tal lei não se situava no âmbito de aplicação do direito comunitário, para efeitos de um controle de compatibilidade com a CEDH. A este respeito, torna-se esclarecedor um confronto com a jurisprudência Rutili, como se irá ver em seguida

3. 0 acórdão de 28 de Outubro de 1975 , Rutili/Ministro do Interior ${ }^{37}$, proferido em resposta a duas questōes prejudiciais de interpretação do artigo $48, n^{0} 3$, do Tratado remetidas por um tribunal francês, afirma claramente a relevância juridico-comunitária dos atos legislativos e regulamentares nacionais (mas também dos atos administrativos praticados em sua execução) derrogatórios das liberdades fundamentais previstas pelo Tratado. O TJ declarou com efeito, que embora os Estados-Membros permaneçam, quanto ao essencial, livres de determinar, nos termos da reserva prevista pelo artigo $48, n^{0} 3$, de acordo com as suas necessidades nacionais, as exigências de ordem públi- 
ca, "todavia, no contexto comunitário e, designadamente, enquanto justificação de uma der. rogação aos principios fundamentais da igualdade de tratamento e da liberdade de circulação dos trabalhạdores, tal conceito deve ser entendido estritamente, pelo que o seu alcance não pode ser determinado unilateralmente por cada um dos Estados-Membros sem controle dos orgãos da Comunidade" 38 .

Por outro lado, em resposta à questão de saber qual o sentido preciso a atribuir ao termo "[limitações] justificadas", constante do artigo $48, n^{\circ} 3$, o TJ declarou que a justificação das medidas nacionais que se reportam à salvaguarda da ordem pública e, nomeadamente, à politica de estrangeiros, deve ser apreciada à luz de todas as regras de direito comunitário que visam, por um lado, limitar o poder discricionário dos Estados-Membros na matéria e, por outro, dos Estados-Membros na matéria e, por outro, garantir a defesa dos direitos das pessoas sujei-
tas, por esse motivo, a medidas restritivas apesar de nenhuma questão prejudicial relativa à $\mathrm{CEDH}$ lhe ter sido colocada, o TJ constatou que, no seu conjunto, tais regras de direito comunitário configuram-se como a manifestação especifica de um principio mais geral consagraespecifica de um principio mais geral consag
do pelos artigos $8^{\circ}, 9^{\circ}, 10$ e 11 da $\mathrm{CEDH}^{40}$.

do pelos artigos $8^{\circ}, 9^{\circ}, 10$ e 11 da $\mathrm{CEDH}^{40}$.
Este passo da fundamentação do acórdão Rutili permitia vários desenvolvimentos jurisprudenciais, tendo em conta que, ao tempo, já se encontrava estabelecido no ordenamento comunitário o principio segundo o qual os direitos fundamentais são parte integrante dos principios gerais de direito, cuja observância o TJ gapios gerais de direito, cuja observância o TJ ga-
rante (só não tinha ainda sido reconhecido o significado particular da CEDH para esse efeito).

Em primeiro lugar, fundando-se no acórdão Rutili, o TJ poderia vir a considerar-se competente para, na falta de regras especificas de direito comunitário, apreciar a compatibilidade, com o "principio mais geral consagrado pelos artigos $8^{\circ}, 9^{\circ}, 10$ e 11 da CEDH", das medidas egislativas ou regulamentares dos EstadosMembros derrogatórias não só da liberdade de circulação dos trabalhadores na acepção do artigo $48, n^{0} 3$, mas também da liberdade de circulacão de mercadorias na acepcão do artigo 36 . culibe de mercadorias na acepcào do artigo 36. da liberdade de estabelecimento, na acepção do artigo 56 e da liberdade de prestação de serviços na acepção do artigo 66 .
Em segundo lugar, em desenvolvimento da jurisprudência Rutili, o TJ poderia vir a tornar uma tal competência de controle extensiva aos atos legislativos e regulamentares (não discriminatórios) dos Estados-Membros restritivos das liberdades comunitárias fundamentais, mas eventualmente suscetiveis de se justificar, por exigências imperativas de interesse geral, à face dos artigos 30, 48, 52 e 59.

Por último, baseando-se na mesma jurisprudência, o $\mathrm{TJ}$ poderia vir a considerar-se, mais genericamente, competente para apreciar a compatibilidade com a CEDH de quaisquer atos normativos dos Estados-Membros que apresentem um elemento de conexão com o direito comuniexpressamente defendida pelo advogado-geral Alberto Trabucchi, nas conclusòes apresentadas em 2 de Junho de 1976, no processo Watson e Belmann, supracitado. Vale a pena transcrever o excerto pela clareza e também pela exata consideração de todas as implicações da tese em questão:

"Pode deduzir-se [do acórdão Rutili] que o respeito pelos principios fundamentais relativos à proteção dos direitos do homem (...) pode igualmente revestir-se de importância no âmbito de aplicação do direito comunitário com vista à determinação da legalidade da atitude do Estado em relacão ao direito a uma liberdade que o Tratado reconhece aos particulares.

É certo que, ao contrário dos atos do executivo comunitário, os atos dos Estados estão sujeitos ao controle dos respectivos órgãos jurisdicionais internos que, com o Tribunal Europeu dos Direitos do Homem, asseguram já uma proteção eficaz dos direitos fundamentais. Apesar disso, também o Tribunal de Justiça, sem usurpar as competências próprias de outros órgãos jurisdicionais, poderá censurar a violação de um direito fundamental por uma autoridade estadual, senão na mesma medida em que poderia fazêlo no quadro do controle da validade dos atos comunitários, pelo menos na medida em que o direito fundamental cuja violação è alegada pode reportar-se à proteção de um direito econômico que constitua um dos objetos especíicos do Tratado. Na falta de tal nexo a ação do Estado em relação aos particulares não seria suscetivel de desempenhar qualquer papel no sistema comunitário, nem mesmo no plano processual" 42

4. Confrontando agora o caso Cinéthèque com 0 caso Rutili, há que constatar que, par além de se situar no dominio da livre circulação de mercadorias, o primeiro se distingue ainda do segundo num ponto muito significativo. que, neste último, as disposições de direito nacional em causa podiam considerar-se, antes de mais, como regras de execução de uma diretiva do Conselho ${ }^{43}$ e não como disposiçōes suscetiveis de beneficiar diretamente, sendo esse o caso das exceçōes previstas pelo artigo $48, \mathrm{n}^{\circ} 3$.

Mas o que importa salientar é que o acórdão Cinéthèque rejeitou implicitamente a segunda possibilidade deixada em aberto pelo acórdão Rutili, isto é, de o TJ se considerar competente para examinar a compatibilidade com a CED dos atos estaduais restritivos da liberdade de circulação de mercadorias de caráter não discriminatório, eventualmente suscetiveis de se justificar, por exigências imperativas de interesse geral, perante o artigo 30 do Tratado.

Todavia, para esse efeito, o TJ não interpre tou o conceito de "âmbito da competência do legislador nacional", nem no sentido da competência exclusiva do legislador nacional nem, muito menos, de âmbito de competência isento do controle do TJ no quadro do artigo 177. Com efeito, para concluir que as disposições da le francesa em questão, apesar dos seus potenciais entraves ao comércio intracomunitário de videocassetes podiam, ainda, ser consideradas compativeis com o artigo 30 , o TJ examinou-as sob vários aspectos. Primeiro, quanto à eventual natureza discriminatória, para concluir que tais disposiçōes eram indistintamente aplicáveis às videocassetes fabricadas no território nacional e às importadas. Depois, quanto ao seu objetivo, para concluir que o mesmo era de caráter cultural (encorajamento da criação de obras cinematográficas sem distinção de origem), justificável perante o direito comunitário. Por fim, à luz do principio da proporcionalidade, para concluir que tais disposiçōes não iam alêm do necessário para garantir tal objetivo ${ }^{44}$. O que precede parece tornar inconcludente a contraposção operada pelo acórdảo Cinéthèque entre "âm bito próprio do direito comunitário" e "âmbito da competência do legislador nacional".

Em todo o caso, se de acordo com a própria jurisprudência do $\mathrm{TJ}^{45}$, a proteção dos direitos fundamentais se conta, ao lado do principio da necessidade, da proporcionalidade e outros, entre os princípios gerais do direito comunitário cuja observância é garantida pelo $\mathrm{TJ}$, resulta de fato incoerente que o $\mathrm{TJ}$, após ter examinado a lei em questão sob os aspectos acabados de enumerar, a fim de determinar se ela se justificava perante o artigo 30 , se tenha declarado incompetente para examinar a compatibilidade da mesma com a liberdade de expressão consagrada no artigo 10 da CEDH, tal como lhe fora solicitado pelas sociedades recorrentes e interCom efelo, em tais clircunstancias, o TJ deve Corantr que uma lei como a exam, o Tu deve ta não que uma lei como a examinada respeia no as disposiçoes especificas do Tratado ou do direito adotado em sua execução, mas também os principios mais gerais que, tal como resultam da $\mathrm{CEDH}$, integram igualmente o bloo de legalidade comunitária.

5. Dito isto, importa delimitar com precisão 0 alcance do acórdão Cinéthèque. A este propósito, cabe sobretudo salientar que, dado o seu contexto específico, ele não precludia a possibilidade de o TJ se considerar competente para fiscalizar a compatibilidade com a CEDH de um ato normativo de um Estado-Membro à primeira vista proibido por conter entraves discriminatórios a uma das liberdades fundamentais da Comunidade, a fim de determinar se tal ato pode ou não beneficiar das exceções previstas pelos artigos $36,48, n^{0} 3,56$ e 66 . Para este efeito, 0 principio do respeito pelos direitos fundamentais podia, pois ombrear com os principios da necessidade e da proporcionalidade e todos os demais principios gerais do direito comunitário cuja observância é garantida pelo TJ. E isto independentemente da concreta intermediação de um ato de fonte comunitária.

Por outras palavras, o acórdão Cinéthèque, apesar de rejeitar o segundo dos desenvolvimentos jurisprudenciais permitidos pelo acórdão Rutili (atrás enumerados), não precludia o primeiro. Quanto ao terceiro desenvolvimento, dado o seu caráter genérico, ele não podia deixar de ficar, de algum modo, comprometido pela inter- 
pretação restritiva do conceito de "âmbito de aplicação do direito comunitário" dada pelo acórdão Cinéthèque ${ }^{47}$.

C - O "Âmbito de Aplicação do Direito Comunitário" Restrito às Normas Nacionais de Execução do Direito Adotado Pela Comunidade - I: o Acórdão Demirel

1. A jurisprudência posterior ao acórdão $\mathrm{Ci}$ néthèque veio confirmar que o $\mathrm{TJ}$ não estava disposto a concretizar de imediato as possibilidades que lhe abria o acórdão Rutili no sentido de assumir competência para controlar a compatibilidade, com a CEDH, dos atos legislativos ou regulamentares dos Estados-Membros com relevância jurídico-comunitária, mas sem conteúdo executivo relativamente $\mathrm{a}$ atos adotados teúdo executivo relativamente a atos adotados
pela Comunidade. Dito de outro modo, os casos que o TJ foi subseqüentemente chamado a decidir deram-lhe o ensejo de confirmar que, fora de um contexto normativo integrando disposições de direito comunitário derivado, de alguma forma executadas pelas disposiçoes nacioma forma execuladas pelas disposicoes nacionais litigiosas, ele se consideraria incompetente para apreciar estas últimas à luz da $\mathrm{CEDH}$, independentemente do fato de as mesmas patentearem qualquer outro nexo com o ordenamento comunitário.

A este respeito, há que referir duas espécies de acórdãos: por um lado, o acórdão de $30 \mathrm{de}$ de acordas: por, um lad Setembro de 1987, Demirel/Cidade de Schwäbisch Gmünd ${ }^{48}$, em que o non possumus do $\mathrm{TJ}$ foi expressamente afirmado com fundamento na ausência de um contexto normativo como o que acaba de delinear-se; por outro lado os acórdãos de 15 de Maio de 1986, Johnston/Chief Constable of the Royal Ulster Constabulary ${ }^{49}$ de 25 de Novembro de 1986, Klensch/Secrétaire d'État ${ }^{50}$, de 13 de Julho de 1989, Wachauf/ Bundesamt für Ernährung und Forstwirts chaft ${ }^{51}$, e de 24 de Março de 1994, Bostock, supracitado, em que o possumus do TJ se fundamentou na existência de uma típica relação de execucão entre o direito comunitário e o direito execuçà nacional cuja compatibilidade com os direitos undamentais estava em questão.

2. No processo prejudicial Demirel a questão da competência do TJ para verificar a compatibilidade com ao CEDH de uma disposição de direito nacional suscitou-se num contexto muito particular. $\mathrm{O}$ juiz nacional remeteu ao $\mathrm{TJ}$ duas questōes prejudiciais relativas à interpretação de um acordo de associação misto celebrado em 1963 entre, por um lado, a Comunidade Européia, juntamente com os EstadosMembros e, por outro lado, a Turquia. 0 juiz a quo tinha que decidir da aplicabilidade ou não ao caso concreto de uma disposição de direito alemão que aumentou de três para oito anos o periodo de residência ininterrupta e regular no respectivo território, como condição para os cidadãos de paises tercéiros terem direito na Alemanha ao Reagrupamento familiar. Perante 0 tribunal nacional estava pendente um recurso interposto de uma decisão administrativa de expulsão de uma cidadã turca grávida e com com 0 undamento de que o marido ainda não residia há oito anos na Alemanha (embora ai residisse há mais de três anos) e, por conseguinte, não tinha direito ao reagrupamento familiar.

Concretamente, o juiz nacional perguntava ao $\mathrm{TJ}$, em primeiro lugar, se determinadas disposiçōes do acordo de associação CEE-Turquia continham uma proibição, diretamente aplicável na ordem interna dos Estados-Membros, de introduzir novas restriçōes à liberdade de circulação dos trabalhadores turcos licitamente instalados no respectivo território; em segundo lugar, o juiz nacional pretendia saber se o conceito de livre circulação na acepção do acordo de associa to familiar, à semelhança do que vigora para os "cidadãos da Comunidade".

Relativamente à segunda questão, tratavase, no fundo, de saber se, para considerar o direito ao reagrupamento familiar como parte integrante da liberdade de circulação, era necessária uma disposição que expressamente o previsse, à semelhança do artigo 10 do Regulamento do Conselho $\mathrm{n}^{\mathrm{0}} \mathrm{1612/68}$, de 15 de Outubro de 1968, relativo à livre circulação dos trabalhadores na Comunidade e adotado em execução do artigo 48 do Tratado, ou se, para tanto, bastaria aplicar o principio do respeito pelos direitos fundamentais tal com os garante designadamente a CEDH. Mais precisamente, o TJ foi instado a pronunciar-se sobre a aplicabilidade ao caso concreto do artigo $8^{\circ}$ da CEDH, que consagra o direito fundamental à vida privada e familiar.
Em resposta à primeira questão prejudicial, o TJ declarou que as disposições do acordo de associação em causa não eram invocáveis em tribunal contra a introdução pelos EstadosMembros de novas restriçōes à livre circulação dos trabalhadores turcos licitamente instalados nos respectivos territórios. A fim de fundamentar a constatação de que não se tratava de dis posiçōes suficientemente precisas e incondicionais para poderem reger diretamente a circulação de tais trabalhadores, o TJ salientou designadamente $o$ fato de 0 acordo de associação não ter sido "regulamentado" por nenhuma disposição adotada pelo órgão competente (o conselh de associação) proibindo novas restrições ao reagrupamento familiar ${ }^{52}$.

Chegado a esta conclusão, o TJ considerou desnecessário responder à segunda questão prejudicial, ou seja, a de saber se a liberdade de circulação dos trabalhadores turcos prevista pelo acordo de associação CEE-Turquia incluia o direito ao reagrupamento familiar. Entendendo ainda assim, que 0 artigo $8^{\circ}$ da CEDH tinha "uma incidència eventual" na resposta a dar a tal questảo, o TJ prosseguiu nos seguintes termos:

"28. (...) Ora, no caso concreto, tal como resulta da resposta dada à primeira questão, não existe, atualmente, uma norma de direito comunitário que defina as condições em que os Estados-Membros devem autorizar o reagrupamento familiar dos trabalhadores turcos licitamente instalados na $\mathrm{Co}$ munidade. Por conseguinte, a regulamentação nacional em causa no processo principal não tinha que executar uma disposição d direito comunitário. Nestas condiçōes, o Tri bunal de Justiça não tem competência para apreciar a compatibilidade, com os principios consagrados pelo artigo $8^{0}$ da Convenção Européia dos Direitos do Homem, de uma regulamentação nacional como a que está em causa".

3. Perante este excerto, fica mais clara a interpretação dada pelo $\mathrm{TJ}$ ao conceito de "âmbito de aplicação do direito comunitário", em função da qual delimita a sua competência para fiscalizar os atos legislativos e regulamentares do Estados-Membros no que toca à sua compatibilidade com ao $\mathrm{CEDH}$. O que não fica, porém nada claro é que com uma tal interpretação o $\mathrm{TJ}$ não tenha concretamente admitido na $\mathrm{Co}$ munidade uma medida incompativel com um direito fun

O TJ teve decerto razão ao declarar que as disposições do acordo de associação em causa
não bastavam para que o interessado pudesse impugnar com êxito, perante o tribunal nacional, a nova restrição à liberdade de circulação dos trabalhadores turcos licitamente instalados na Alemanha (prolongamento do prazo de residência para efeitos do reagrupamento familiar introduzida pela disposição de direito nacional em questão. Mas tal constatação traduz-se num juízo de natureza meramente adjetiva. A verdadeira questão substantiva era a de saber se tal disposição nacional violava ou não o direito fundamental à vida privada e familiar previsto pelo artigo 80 da CEDH e tutelado qua tale pelo ordenamento comunitário. $\mathrm{E}$ se houvesse que concluir-se pela afirmativa, seria dever indeclinável do $T J$ vincular o tribunal nacional a aplicar diretamente 0 artigo $8^{\circ}$ da $\mathrm{CEDH}$, enquanto regra superior de direito comunitário, contra a disposição nacional litigiosa ${ }^{53}$

D - O "Âmbito de Aplicação do Direito Comunitário" Restrito às Normas Nacionais de Execução do Direito Adotado Pela Comunidade - II: os Acórdãos Johnston Klensch, Wachauf e Bostock

1. Tendo em conta o que precede, compre ende-se facilmente que, num contexto em que as disposições de direito nacional litigiosas tinham sido adotadas em execução de uma diretiva comunitária, o TJ não hesitasse em recorrer à CEDH, a fim de fornecer ao tribunal a quo todos os elementos de interpretação necessários à apreciação, por parte deste, da conformidade de tais disposições com os direitos fundamentais garantidos no ordenamento comunitário. É o que atesta, em primeiro lugar, o acórdão prejudicial Johnston, supracitado.

No caso concreto, tratava-se de aquilatar da compatibilidade com ao Diretiva 76/207 do Conselho, de 9 de Fevereiro de 1976, relativa à aplicação do principio da igualdade de tratamento entre homens e mulheres, de uma disposição do Sex Discrimination Order vigente na Irlanda do Norte que declarava contenciosamente inimpugnável um determinado tipo de ato adminis- 
trativo de caráter potencialmente discriminatório em razão do sexo. Após ter recordado que 0 artigo $6^{0}$ da diretiva em causa obriga os Estados-membros a introduzir nas respectivas or dens juridicas as disposiçōes necessárias para permitir a quem se sinta lesado por uma discriminação de ordem sexual "fazer valer os seu direitos por via jurisdicional", o TJ salientou que "o controle jurisdicional imposto por este artigo é expressão de um principio geral de direito ( igualmente consagrado pelos artigos $6^{\circ}$ e 13 da CEDH"54

Numa formulação e num contexto que lembram os do acórdão Rutili, o acórdão Johnston reiterou implicitamente a possibilidade de $0 \mathrm{~T}$ assumir competência para fiscalizar a compatibilidade como a CEDH dos atos legislativos regulamentares nacionais com relevância juridico-comunitária, sem necessidade da interposição de uma diretiva ou de um regulamento comunitários.

2. Por outro lado, no acórdão prejudicia Klensch, supracitado, o TJ considerou-se igualmente competente para apreciar as disposicōes de direito nacional adotadas em execução de regulamentos comunitários (no caso concreto em sede de politica agricola comum), à luz do "principio geral de igualdade que faz parte dos principios fundamentais do direito comunitário A fundamentação estava, de resto, facilitada pelo fato de o direito fundamental à igualdade encontrar uma "expressão especifica" no artigo 40 $\mathrm{n}^{\circ} 3$, segundo parágrafo, do Tratado, que proi be qualquer discriminação entre produtores ou consumidores da Comunidade no âmbito das organizaçōes de mercado.

$\mathrm{Na}$ interpretação do TJ, uma tal disposição visa todas as medidas relativas à organização comum dos mercados agricolas, independentemente da autoridade que os estabelece. Isto sig nifica, mais concretamente, que ao adotarem os atos normativos necessários à implementação de uma organização comum de mercado, os Es tados-Membros estão também vinculados pelo artigo $40, \mathrm{n}^{0} 3$, do Tratado ${ }^{55}$.

3. Subseqüentemente, no acórdảo prejudicial de 13 de Julho de 1989, Wachauf (proferido também no âmbito da politica agricola comum) o TJ declarou, de forma mais genérica, que as exigências decorrentes do principio da proteça dos direitos fundamentais na ordem juridica comunitária vinculam igualmente os EstadosMembros sempre que estes executam normas ais, legislativos ou regulamentares, adotados no exercicio dessa competência executiva devem "em toda a medida do possivel", observar tais exigências.

No caso concreto, o $\mathrm{TJ}$ considerou que a regulamentação comunitária cuja interpretação lhe era pedida (Regulamento no $857 / 74$ do Conselho e Regulamento no 1371/84 da Comissão), (1ssão), dava às autoridades nacionais competentes uma margem de apreciação suficientemente ampla para que estas adotassem os necessários regulamentos de execução em conformidade com 0 imperativo de proteção dos direitos fundamentais. Para esse efeito, o próprio $\mathrm{TJ}$ indicou alernativamente 0 conteudo que deveriam entar as disposicóes de execuça naclonasso-

Em conseqüência deste acórdão prejudicial,
o juiz a quo anulou parcialmente um regulamento de execução nacional de conteúdo diverso do indicado pelo TJ, com fundamento em violação do direito fundamental à propriedade ${ }^{57}$.

Do acórdão Wachauf resulta claro, em primeiro lugar, um ponto de grande significado para o tema do presente estudo: a circunstância de 0 to normativo de execução nacional ter sido adotado no exercicio de um amplo poder discricionário não constitui um limite à competência do TJ para 0 apreciar, no quadro do artigo 177 , do ponto de vista da compatibilidade com os direitos fundamentais protegidos no ordenamento comunitário. Com efeito, dado o seu caráter absoluto, o dever de os Estados-Membros respeitarem os direitos fundamentais quando executam normas de fonte comunitária não pode depender do grau de discricionariedade legislativa ou administrativa de que dispõem para esse efeito 58

Do mesmo acórdāo decorre, por outro lado, que se não for de todo em todo possivel aos competentes órgãos dos Estados-Membros executar uma disposição de direito comunitärio sem violar direitos fundamentais, isso significa que 0 controle do TJ deverá incidir, antes de mais, sobre tal disposicão comunitária, podendo em tal caso levar à anulação da mesma.

4. A competência do TJ para aquilatar da compatibilidade, com os direitos fundamentais, das regras de direito nacional adotadas em exe- cução de disposições comunitárias fundamenta-se, em última análise, na própria natureza da ordem juridica comunitária. Como efeito, esta exige normalmente a intervenção, a titulo complementar, do legislador nacional (pense-se nas diretivas mas também nos próprios regulamentos comunitários ${ }^{59}$ ). Mais genericamente, os Estados-Membros atuam como "poder executivo" da Comunidade (em nome e/ou por conta dela) numa extensão largamente superior à que se verifica em qualquer Estado federal ${ }^{60}$.

Do que precede resulta que a autoria formal do ato normativo litigioso não pode, definitivamente, ser tida por critérios adequado para delimitar a competência fiscalizadora do $\mathrm{TJ} \mathrm{em}$ matéria de direitos fundamentais. Tratando-se da execução do direito comunitário, o mesmo principio que leva o $\mathrm{TJ}$ a fiscalizar a conformidade com os direitos fundamentais dos atos praticados pelos competentes orgas da Com ticados pelos comptentes orgaos da Comunidade (pela Comissão e também pelo Conselho) - princípio da Comunidade de Direito - deve valer igualmente para os atos dessa natureza praticados pelos competentes órgãos dos Estados-Membros. E isto sem prejuizo do fato de, em relação a estes últimos atos, os poderes de fiscalização do TJ coexistirem, em determinados Estados-Membros, com os poderes de fiscalização mais vastos dos respectivos tribunais constitucionais, igualmente em sede de direitos fundamentais. Adiante se voltará a este tema.

5. Um acórdão recente do $\mathrm{TJ}-\mathrm{o}$ supracitado acórdão Bostock, de 24 de Março de 1994 veio, de alguma forma, pôr em causa os principios fixados pelo acórdão Wachauf quanto à competência fiscalizadora do TJ que tem estado a ser analisada.

No caso concreto, o TJ, embora não pondo em causa 0 fato de que as normas legislativas estaduais litigiosas, por terem sido adotadas em execução de regulamentações comunitárias, se situavam no "âmbito de aplicação do direito cosituavam no "ambito de aplicação do direito co-
munitário"6l, acabo por admitir que as mesmas munitário"61, acabo por admitir que as mesmas principio da igualdade. Ora, no acórdão Wachauf, o TJ tinha considerado, diversamente, que uma regulamentação adotada pela Comunidade que estabelecesse uma solução de principio idêntica à que resultava, para o caso Bostock, da legislação nacional em causa seria incompativel com as exigências decorrentes da proteção dos direitos fundamentais na ordem jurídica comunitária ${ }^{62}$.

A divergência do acórdão Bostock relativamente à jurisprudência Wachauf não parece justificada. Como já se demonstrou, o fato de um Estado-Membro dispor, como no caso sub judi$c e$, de uma ampla margem de discricionariedade para a gestão de uma politica comunitária não exime a Comunidade nem, em especial, 0 $\mathrm{TJ}$ da responsabilidade de garantir que, no deTempenho dessa tarefa, os amenais protegidos pelo ordenamento comunitário serão, de qualquer forma, respeitados ${ }^{63}$.

E - Um Passo Intermédio na Evolução do Acórdão Cinéthèque para o Acórdão ERT: 0 Acórdão Bond van Adverteerders/Estado Neerlandês

1. Viu-se anteriormente que, nos primeiros processos em que foi confrontado, no contexto da "integração negativa", com a questão da eventual incompatibilidade de determinadas disposiçōes de direito nacional com a CEDH (Royer e Watson e Belmann, supracitados), o TJ não respondeu a tais questōes - nem mesmo quando isso the foi expressamente sugerido pelo advogado-geral

Nesses casos, o TJ limitou-se a decidir as respectivas questōes prejudiciais apenas com base em disposições específicas do Tratado e de atos adotados em sua execução, deixando subentendido que a eventual incompatibilidade com a CEDH de uma lei ou de um regulamento nacionais não constituia, em principio, uma questão de direito comunitário. Conferiu, no entanto, uma tal extensão e um tal alcance às disposiçōes do Tratado em matéria de liberdade de circulação e de proibição de discriminações em razão da nacionalidade que o imperativo de proteção dos direitos fundamentais podia considerar-se, dessa forma, plenamente satisfeito. Era de fato possivel questionar legitimamente 0 real interesse de um recurso cumulativo à $\mathrm{CEDH}$ como parâmetro de validade dos atos estaduais litigiosos ${ }^{64}$

2. É neste contexto que cabe situar o acórdão de 26 de Abril de 1988, Bond van Adverte erders/Estado Neerlandês ${ }^{65}$. No caso concreto, o juiz nacional, a fim de poder decidir da compatibilidade com o direito comunitário de uma 
regulamentação nacional (Kabelregeling) proibindo a difusão por cabo de programas de rádio e de televisão emitidos a partir de outros Estados-Membros, quando tais programas comportassem mensagens publicitárias destinadas especialmente ao público neerlandês ou legendas em neerlandnês, solicitou ao TJ a interpretação em neerlandnês, solicitou ao TJ a interpretação
dos artigos 59 e 56 do Tratado, assim como do

dos artigos 59 e 56
artigo 10 da $\mathrm{CEDH}$.

Estava-se, mais uma vez, no pleno dominio da "integração negativa", precisamente no da liberdade de prestação de serviços e, além disso, não havia à data normas de harmonização adotadas pela Comunidade no setor da radiodifusão e da televisão. Nestas condições, o TJ poderia ser levado a considerar - como, aliás, tho sugeriu expressamente o advogado-geral, baseando-se no acórdão Cinéthèque ${ }^{66}$ - que a regulamentação nacional em causa se situava "num âmbito da competência do legislador nacional" ar-se incompetente para examinar a compatibilidade de uma tal CEDH.

O TJ optou, no entanto, por uma formulação diversa, não excludente da sua competência de controle baseada na CEDH e que pode de alguma forma contribuir para esclarecer retrospectivamente as razōes que o levaram nos anteriores acórdãos Royer e Watson e Belmann a não abordar a questão da eventual aplicabilidade da $\mathrm{CEDH}$. Após ter constatado, em primeiro lugar, que a Kabelregeling comportava restrições à livre prestação de serviços discriminatórias em relação aos nacionais de outros Estados-Membros e, por isso mesmo, proibidas pelo artigo 59 e, em segundo lugar, que tais restriçōes eram insuscetiveis de se justificar por razōes de ordem pública nos termos do artigo 56 , uma vez que contrariavam os principios da necessidade e da proporcionalidade, o juiz comunitários considerou que:

"41. Resulta das respostas dadas às questōes precedentes que proibições de publicidade e de legendagem como as contidas na Kabelregeling são incompativeis com as disKabelregeling são incompativeis com as dis-
posiçoes dos artigos 59 e seguintes do Trataposiçōes dos artigos 59 e seguintes do Trata-
do. Uma vez que tais respostas permitem por do. Uma vez que tais respostas permitem por
si só ao órgão jurisdicional nacional dirimir o litigio que lhe foi submetido, a questão [relativa ao artigo $10^{\circ}$ da CEDH] fica sem objeto". 67
O TJ deixou, assim, implicito que, sendo caso disso, a CEDH podia constituir um elemento complementar de apreciacão com vista a deci(a) damental que apenas atingem os nacionais de outros Estados-Membros, è suscetivel de beneficiar das exceções previstas pelas disposiçōes conjugadas dos artigos 56 e 66 , mas também pelos artigos 36 e $48, n^{0} 3$.

3. No entanto, posteriormente ao acórdão Bond van Adverteerders, o TJ voltou ainda a recorrer à "tática do silêncio" ao ser chamado a interpretar a CEDH, no quadro do artigo 177 do Tratado, a fim de determinar a eventual desaplicação pelo tribunal a quo de uma disposição nacional alegadamente contrária àquele instrumento internacional.

Fê-lo, primeiro, no acórdão de 10 de Julho de 1990. Hansen, relativamente a uma norma nacional prevendo uma modalidade de responsabilidade penal objetiva, adotada em execução de um regulamento comunitário. O TJ limitouse a tomar em consideração, na sua decisão prejudicial, as disposições do regulamento comunitário pertinentes com exclusão do artigo $6^{\circ}$ $\mathrm{n}^{0}$ 2, da CEDH (principio nulla poena sine cul$\mathrm{pa}$, afastando-se do que lhe tinha sugerido o dvogado-geral ${ }^{68}$

O segundo caso em que o $\mathrm{TJ}$ seguiu a mesma tática - acórdão de 30 de Março de 1993, Konstantinidis - mostra-se, no essencial, semelhante ao caso Bond van Adverteerders. Com efeito, o litígio submetido ao órgão jurisdicional nacional, e que levou este a ques prejudicial, podia ser dirimido com base na constatação que a lei alemã em questão era potencialmente discriminatória em relação aos cidadãos gregos estabelecidos na Alemanha e, nessa medida, contrária ao artigo 52 do Tratado. Nesta ótica, tornava-se desnecessário para o TJ tomar expressamente em consideração o direito funcomo lhe haviam sugerido o tribunal a quo e o advogadogeral ${ }^{69}$

Com esta "tática do silêncio", o TJ parece pretender não pautar abertamente as suas decisões pelo objetivo geral politicamente orientado de proteger os valores consagrados na $\mathrm{CEDH}^{70}$ A ser assim, não se pode dizer que tal atitude seja a mais consentânea com a vontade noutros contextos manifestada pelo $\mathrm{TJ}$ de $\mathrm{se}$ assumir como tribunal constitucional da Comunidade Européia. Adiante se voltará a este ponto.

A terminar esta seção, cabe ainda referir um pormenor com interesse: as conclusōes apresentadas no processo que deu origem ao acórdão ERT, a examinar em seguida, sugeriam ao TJ que decidisse de forma idêntica à do acórdão Bond van Adverteerders. Com efeito, o advogado-geral entendia que, no caso concreto, os elementos de apreciação extraídos designadamente do artigo 59 do Tratado bastavam para que 0 juiz nacional pudesse dirimir o litígio no processo principal; em sua opinião, o artigo $10 \mathrm{da}$ $\mathrm{CEDH}$ não fornecia quaisquer novos elementos de apreciação para esse efeito ${ }^{71}$.

\section{F - O "Âmbito de Aplicação do Direito} Comunitário" Alargado às Normas Nacionais Derrogatórias das Liberdades Fundamentais Garantidas Pelo Tratado: o Acórdão ERT

1. A inclusão expressa das normas nacionais que estabelecem derrogaçōes às liberdades comunitárias fundamentais entre os atos que relevam do "âmbito de aplicação do direito comunitário" e, por conseguinte, estão sujeitos à competência fiscalizadora do TJ no que toca à sua compatibilidade com a CEDH, foi pela primeira vez levada a cabo pelo acórdão ERT, supracitado. Tratava-se, no caso concreto, de aquilatar da compatibilidade de uma lei nacional que estabelecia um regime de direitos exclusivos em matéria de televisão com os artigos 30 e 59 do Tratado e 10 da CEDH, no quadro de um litígio opondo a sociedade grega ERT, concessionária dos direitos exclusivos, a uma sociedade municipal de informação que começara a difundir emissōes televisivas.

Em resposta às questões prejudiciais a esse respeito suscitadas por um tribunal grego ao abrigo do artigo 177, o TJ começou por constatar não ser de excluir que o tribunal nacional o único órgão jurisdicional com competência para conhecer dos fatos concretos, como enfaticamente repetiu -, uma vez na posse dos elementos de interpretação solicitados acerca do artigo 59 , viesse a concluir que a lei em questão implicava discriminacões entre emissões televisivas nacionais e emissões televisivas proveni- entes de outros Estados-Membros. Tais discriminações seriam contrárias ao artigo 59 , a menos que a lei em causa pudesse justificar-se por uma das razões indicadas no artigo $56^{72}$. Havia, portanto, que fornecer ao tribunal nacional os necessários elementos de interpretação sobre esta última disposição. A este propósito, o TJ declarou que:

"43. Em particular, sempre que um Estado-Membro invocar as disposições conjugadas dos artigos 56 e 66 para justificar uma regulamentação suscetivel de entravar o exercício da livre prestação de serviços, tal justificação, prevista pelo direito comunitário, deve ser interpretada à luz dos principios gerais do direito e designadamente dos direitos fundamentais. Assim, a regulamentação nacional em causa só poderá beneficiar das exceções previstas pelas disposições conjugadas dos artigos 56 e 66 se for conforme aos direitos fundamentais cuja observância - Tribunal de Justiça garante.

44. Segue-se que em tal caso cabe ao juiz nacional e, sendo caso disso, ao Tribunal apreciar a aplicação de tais disposiçōes, tendo em conta todas as regras do direito comunitário, incluindo a liberdade de expressão, consagrada pelo artigo 10 da Convenção Européia dos Direitos do Homem, enquanto principio geral do direito cuja observância 0 Tribunal de Justiça garante".

No entanto, ao contrário do que fez relativamente às disposiçōes do Tratado em questão (artigos 30, 59, 90, $\mathrm{n}^{\circ} 1$, e $2^{\circ}$ ), o TJ não avançou qualquer elemento de interpretação específico sobre 0 artigo 10 da CEDH, remetendo integralmente tal tarefa para 0 tribunal nacional.

Este acórdão, que encerra uma etapa da evolução da jurisprudência do TJ em matéria de direitos fundamentais, deixa claro que, para serem consideradas justificadas à face da ordem jurídica comunitária, as disposições nacionais derrogatórias das liberdades fundamentais consagradas pelo Tratado devem ser compativeis com a CEDH. O respeito pelos direitos fundamentais torna-se assim, em inteira congruencia com os principios fundamentais vigentes no ordenamento comunitário, uma condição essencial, ao lado, entre outros, dos principios da necessidade e da proporcionalidade, para que aquelas disposições nacionais possam benefici- 
ar das exceçōes previstas não só pelas disposições conjugadas dos artigos 56 e 66 , mas também pelos artigos 36 e 48, no 3 . O TJ aceita agora a tese segundo a qual uma norma nacional derrogatória na acepção das disposições acabadas de mencionar, que não viole qualquer disposição especifica de direito comunitário primápo de violar o "bloco de legalidade comunitária", tornando-se, por conseguinte, inaplicável pelos tribunais nacionais por força do princípio do primado 73

Viu-se anteriormente que o $\mathrm{TJ}$ rejeitou implicitamente tal posição, embora no contexto juridico diferente do acórdão Cinéthèque. Verse-á em seguida que já poderia ter confirmado a orientação fixada no acórdão ERT num contexto juridico idêntico ao do acórdão Cinéthèque.

2. À primeira vista, o acórdão de 4 de Outubro de 1991, Society for the Protection of Unborn Children Ireland (SPUC) ${ }^{74}$, nada acrescenta ou retira à definição, dada pelo acórdão ERT, da competência do $\mathrm{TJ}$ no que toca ao controle da compatibilidade das normas nacionais com a CEDH. No caso concreto, o TJ foi chamado a julgar se o direito comunitário se opõe à proibição aplicável sem distinção de nacionalidade na Irlanda e jurisprudencialmente extraida do artigo $40, \mathrm{n}^{\circ} 3$, terceiro parágrafo, da respectiva constituicão (que consagra expressamente o direito à vida do nascituro), de divulgar informaçōes sobre clinicas que praticam legalmente a interrupção voluntária da gravidez noutro Estado-Membro.

O TJ orientou o seu raciocinio a partir de uma jurisprudência constante segundo 0 qual os artigos 59 e seguintes só regem as prestaçōes de serviços de caráter interestadual e não puramente intra-estadual, para concluir pela ausência, no caso concreto, de qualquer elemento transfronteiriço suscetivel de colocar a proibição de difundir as informações em causa sob a alçada do artigo 59. Segundo o TJ, o nexo entre a difusão de tais informações (levada a cabo por associações de estudantes irlandesas) e as interrupçōes médicas de gravidez praticadas pelas clinicas de outro Estado-Membro (o Reino Unido) era "demasiado ténue" para tornar aplicável 0 artigo 59. Mais precisamente, as informações a que se referiam as questōes prejudiciais não eram difundidas "por conta do operador econômico estabelecido noutro Estado-Membro", antes constituindo "uma manifestação da liber dade de expressão e de informação, independente da atividade econômica exercida pelas clinicas estabelecidas noutro Estado-Membro"75 Não se situando, portanto, a disposição de direito nacional em causa no âmbito de aplicação do direito comunitårio, o TJ declarou-se incompetente para fornecer ao tribunal a quo quaisquer elementos de interpretação acerca do artigo 10 da CEDH, invocado pelos recorridos no processo principal, de molde a permitir-lhe apreciar a compatibilidade com esta disposição da proibição de direito nacional litigiosa.

Com esta solução o $\mathrm{TJ}$ parece ter pretendido evitar sobretudo um exame de fundo, dada a delicadeza da questão, diretamente relacionada com o tema do aborto. E esta suposição é tanto mais plausivel quanto é certo que o elemento transfronteiriço podia identificar-se sem dificuldades de maior no caso concreto. 0 próprio adogado-geral o fez com muito precisao. $\mathrm{E}$, de resto, esclarecedor o confronto do acórdão com as conclusões.

$O$ advogado-geral começou por considerar, ao invés do acórdão, que a disposição nacional em questão se incluia no âmbito de aplicação do direito comunitário, desde logo por proibir aquilo que constitui um corolário da liberdade, garantida pelo Tratado, de prestar e de receber servicos noutros Estados-Membros, ou seja, a difusão de informações (a titulo de atividade econômica ou não) sobre tais serviços ${ }^{76}$. Nessa medi$\mathrm{da}$, tal disposição de direito irlandês era prima facie suscetivel de entravar a circulação intracomunitária de serviços. Por conseguinte devia er-se por contrária ao artigo 59 do Tratado, mesmo não sendo discriminatória. A menos, evidentemente, que pudesse justificar-se por razões imperativas de interesse geral. $\mathrm{O}$ advogado-geral chegou à conclusão afirmativa após ter submetido a disposição nacional litigiosa aos testes da compatibilidade do seu objetivo com o direito comunitario, da proporcionalidade e, por ultimo mas não menos importante, da sua compatibilidade com a liberdade de expressaonsagrada no artigo 10 da $\mathrm{CEDH}^{77}$. Quanto a este último aspecto, 0 advogado-geral salientou, em especial, a delicadeza da operação de concordância prática de dois direitos fundamentais tão sensiveis como, por um lado, o direito à liberda- de de expressão e, por outro lado, o direito à vida intra-uterina no Estado-Membro em cau$\mathrm{sa}^{78}$.

Apesar do caráter evasivo do acórdão em análise, dele não deixa de resultar que, no caso de as informações proibidas serem difundidas diretamente ou "por conta de" uma clinica esta belecida noutro Estado-Membro, a disposicão restritiva de direito nacional em causa seria conrestritiva de direito nacional em causa seria con-
siderada como situada no âmbito de aplicação siderada como situada no âmbito de aplicação do direito comunitário. Em tal caso, o TJ, na esteira da jurisprudência ERT e contrariamente ao acórdão Cinéthèque, não poderia deixar de se declarar competente para submeter a disposição nacional em questão ao testa de compatibilidade com o artigo 10 da $\mathrm{CEDH}$; e isto ainda que os outros testes (necessidade, proporcionalidade, etc.) eventualmente apontassem no sentido da justificação de tal disposição, po razōes imperativas de interesse geral, à face do artigo 59 do Tratado ${ }^{79}$. Com efeito, sem a passagem no teste dos direitos fundamentais, isto é, sem a constatação da sua compatibilidade com a liberdade de expressão, a disposição nacional em causa, jurisprudencialmente extraida do ar tigo 40.3.3 da Constituição irlandesa, não poderia ter-se por legal perante o ordenament comunitário

\section{G - Observações Finais}

1. A aplicação, por extensão, dos parâmetros comunitários relativos à proteção dos direitos fundamentais aos atos normativos dos Estados-Membros evoca irresistivelmente 0 processo que nos Estados Unidos foi designado por incorporation e que se iniciou com 0 acórdão da Supreme Court de 8 de Junho de 1925, Gitlow $v$. New York ${ }^{80}$. Tal processo culminou com a aplicação sistemática, pela Supreme Court, do parâmetro de validade constituido pelo catálog de direitos fundamentais consagrados nos Aditamentos à Constituição federal, não só aos atos normativos dos órgãos federais, mas também aos atos da mesma natureza imputáveis aos Esta dos federados. Até então, o catálogo federal servia de parâmetro de validade exclusivamente aos atos dos órgãos federais; os atos dos órgãos es taduais apenas estavam sujeitos a um controle de validade à face da respectiva constituição.
Para tornar o seu controle de constitucionalidade extensivo aos atos estaduais, a Supreme Court baseou-se no XIV Aditamento à Constituição federal, ratificado em 23 de Julho de 1868, que veda aos Estados "fazer ou executar leis que restrinjam as prerrogativas e garantias ma pessoa da vida, liberdade ou propriedade sem observância dos trâmites legais ou recusar a qualquer pessoa de sua jurisdição a igualdade perante a lei". Mais concretamente, para aquele efeito, a Supreme Court "incorporou", ou seja, acrescentou a esta disposição os direitos fundamentais constantes dos dez primeiros aditamentos à mesma constituicão (liberdade de religião, de expressão, direito à liberdade e à segurança, direito de propriedade privada, garantias de processo criminal etc.). A operação pretoriana assim levada a cabo saldou-se, portanto, pela sobreposição de um catálogo de direitos fundamentais e de um controle federais aos existentes em cada Estado ${ }^{81}$

No entanto, as diferenças entre o processo de incorporation e o processo de extensão da competência do $\mathrm{TJ}$ que tem estado a analisarse são mais do que as semelhanças. Por um lado, enquanto que o primeiro apenas integra uma unica fase de caráter pretoriano, o segundo integra duas, uma vez que, como se viu, a própria "incorporação" no ordenamento comunitário de um catálogo não escrito de direitos fundamentais já constitui, por si só, uma etapa de caráter puramente pretoriano. Por outro lado, enquanto que o controle da Supreme Court é generalizado e, portanto, tipicamente federal, abarcando em principio todo e qualquer ato normativo dos Estados e podendo saldar-se pela declaracão de nulidade do ato em questão, o controle do $\mathrm{TJ}$ apenas pode ter lugar se se verificar uma conexão entre 0 ato do Estado-Membro em causa e o direito comunitário, não podendo, em caso algum, saldar-se pela declaração de nulidade desse ato.

Tudo isto não é, afinal, senão o reflexo da diferença que vai de uma entidade que dispõe da "competência da competência", como um Estado federal, a uma entidade que apenas dispõe de uma "competência de atribuição" como a Comunidade Européia. 
2. A caracteristica essencial da Comunidade a que acaba de aludir-se torna dificil, parecendo que não, a exata delimitação do âmbito de competência do TJ. Isto contribui, de alguma forma, para explicar o fato de a jurisprudência anteriormente analisada, apesar da evodência anteriormente antisada, de evoução signilicativa, não ter ainda logrado revestir-se da certeza e da previsibilidade desejáveis no que respeita ao preenchimento do conceito indeterminado de "disposiçōes de direito nacional situadas no âmbito de aplicação do direito comunitário", para efeitos do controle de compatibilidade com a CEDH. A este respeito, cabem algumas breves observações.

Antes de mais, cumpre salientar que o que acaba de afirmar-se não põe em causa a existência de tipos de casos ainda não julgados pelo TJ relativamente aos quais se não suscitam a priori dúvidas quanto à assunção, por parte deste, da competência para controlar a compatibiidade com a CEDH das disposicoes nacionais lin em questão. Pode citar-se um exemplo concreto, no âmbito das medidas de harmonização com vista ao estabelecimento e o funcionamento do mercado interno: as medidas provisórias adotadas pelos Estados-Membros ao abrigo da cláusula de salvaguarda prevista no artigo 100-A do Tratado "por uma ou várias das razões não ecoouste caso, tendo em conta o carater derrogatorio das medida em causa, é de crer que o TJ, na esteira da jurisprudência ERT, não deixará de proceder a tal controle no quadro do artigo 177 do Tratado.

Por outro lado, focando agora a margem de incerteza acima referida, constata-se que o $\mathrm{TJ}$ tem interpretado o conceito de "disposiçōes de direito nacional situadas no âmbito de aplicação do direito comunitário" de modo tendencialmente restritivo. Mais concretamente, no estádio atual da jurisprudência na matéria, a cir cunstância de uma disposição de direito nacional revelar qualquer outro nexo com o direito comunitario, quara alem do caráter exceutivo ou comunitario, para aĺm do carater exceutivo ou do caráter derroga não implica que, o ipso, o TJ se considere competente para apreciar a compatibilidade de uma tal disposição com a CEDH.

A fim de introduzir a necessária certeza juridica a este respeito pode recorrer-se utilment à distinção de principio entre dominios da competência exclusiva ou predominante da Comu- nidade (cobertos, por exemplo por uma politica comunitária positiva) - em que, não obstante, a ação dos Estados-Membros não está necessariamente precludida - e domínios predominantemente da competência dos Estados-Membros - em que a acão da Comunidade tampouco está totalmente excluida. Enquanto ro caso, a competência de controle do TJ tenderá a abranger o conjunto (compreensivelmente reduzido) das disposições nacionais, no segundo caso, tal competência deverá exercer-se apenas sobre as disposiçōes nacionais que, embora incluidas num domínio globalmente isento desse controle, afetem incidentalmente uma liberdade fundamental da Comunidade ${ }^{82}$. Par além disto, espera-se que a correta aplicação do principio da subsidiariedade contribua igualmente para mais certeza juridica neste contexto, contrariando desde já a tendência para o decréscimo progressivo dos dominios da competência exclusiva do legislador nacional.

Finalmente, parece liquido que a situação ideal neste contexto será aquela em que o particular que, de alguma forma, entre no âmbito de aplicação subjetivo do direito comunitário possa ver os seus direitos fundamentais protegidos de acordo com o "código mínimo comum" constituido pela $\mathrm{CEDH}^{83}$. A consagração da cidadaartigo $8^{\circ}$ do Tratado é, de resto. um argumento juridico novo a favor desta tese. A realização prática de um tal desiderato passa certamente pelo desempenho efetivo, por parte do $T J$, do seu papel de tribunal constitucional da Comunidade, que funcionalmente é, e de garante dos direitos fundamentais dos cidadãos. $\mathrm{E}$ isto tanto mais que, como bem foi salienta$\mathrm{do}^{84}$, as questões relativas aos direitos fundamentais opõem menos a Comunidade aos Estados-Membros do que os particulares às autoridades públicas, sejam elas nacionais ou comunitárias. Nesta perspectiva, a adequada proteção dos direitos fundamentais pode e deve ser vista como uma fonte de legitimação para o TJ.

Com isto nio se pretende, no entanto, afirao nivel da Comunidade, pelas razões anterior mente apontadas ${ }^{85}$, a proteção dos direitos fundamentais passa, em larga medida, pelas próprias ordens constitucionais nacionais. Sobre este tema incidirão as observações que se seguem.
3. No que toca aos sistemas nacionais de proteção dos direitos fundamentais, há que distinguir basicamente dois casos: por um lado, queles Estados-membros em que os particulares, por razões substantivas ou adjetivas, não obtêm a nivel puramente nacional uma proteção idêntica à que resulta dos parâmetros comunitários; por outro lado, os Estados-membros em que os particulares dispōem de um sistema jurisdicional de tutela efetiva dos seus direitos fundamentais cujo vértice é um tribunal constitucional.

É evidentemente no primeiro caso que a competência em análise do TJ tem 0 seu maior impacto. Neste caso, a proteção concedida pelo TJ, em cooperação com os tribunais nacionais nos termos do artigo 177, vem substituir-se parcialmente a uma proteção jurisdicional interna deficitária em matéria de direitos fundamentais. Mais concretamente, nos Estados-membros em que os tribunais não dispōem, à partida, de competência para desaplicar normas legislativas com fundamento em violação da $\mathrm{CEDH}$, como o Reino Unido, a cooperação com o TJ permite-lhes, sendo caso disso, exercer uma tal competência "no âmbito de aplicação do direito comunitário". Tal fato, por sua vez, tenderá a impulsionar a generalização da competência de controle assim adquirida pelos tribunais nacionais a toda $\mathrm{e}$ qualquer norma nacional, no sentido do reforço global dos direitos fundamentais dos cidadãos.

Quanto ao segundo dos casos em referência, é sobretudo de salientar que a fiscalização pelo TJ da compatibilidade com a CEDH das "disposiçoes nacionais que se situam no âmbito de aplicação do direito comunitário" não pode prejudicar a eventual submissão posterior das mesmas ao pleno controle de constitucionalidade por parte dos competentes órgãos nacionais, independentemente de os respectivos parâmetros poderem variar sensivelmente de um EstadoMembro para outro ${ }^{86}$. Desde logo, a CEDH constitui um "parâmetro minimo", podendo os tribunais constitucionais nacionais aplicar um parâmetro mais exigente. Por outro lado, mesmo os atos normativos nacionais de execução de decisōes ou regulamentos comunitários e de transposição de diretivas são, essencialmente. atos da competência própria dos Estados-Membros e não atos praticados ao abrigo de uma delegação ou autorização da Comunidade ${ }^{87}$. Fi- nalmente, ate nos sistemas tipicamente federais, a circunstância de um ato estadual "passar 0 teste" federal da compatibilidade com os direitos fundamentais, não exclui a possibilidade de - mesmo ato vir a ser declarado inconstitucional no Estado em que tenha sido adotado.

4. Merece, por último, uma breve referência 0 tema da articulação entre o TJ e o Tribunal Europeu dos Direitos do Homem (TEDH), órgão jurisdicional encarregado de garantir em última instância o respeito da CEDH pelos vinte e oito Estados ouropeus (dos quais quinze EstadosMembros da Comunidade) que dela são partes contratantes.

A este respeito, importa referir liminarmente que o fato de, no exercicio da sua função jurisdicional, o TJ interpretar e aplicar de forma corrente a CEDH pode dar azo - e já deu mesmo - a divergências de jurisprudência em relação o TEDH. Com efeito e a titulo meramente exemplificativo, enquanto que o $\mathrm{TJ}$ entendeu que 0 direito fundamental à inviolabilidade do domicilio previsto pelo artigo $8^{\circ}, \mathrm{n}^{\circ} 1$, da CEDH apenas abrange o domicilio privado das pessoas singulares, com exclusão das instalaçooes comerciais das empresas, o TEDH interpretou posteriormente a mesma disposição no sentido de que ela protege não só o domicílio privado mas também determinados locais onde se exercem atividades empresariais ${ }^{88}$

Se um tal caso se verificasse entre um tribunal de um Estado parte da CEDH e o TEDH, ele resolver-se-ia mediante o mero exercicio da competência de última instância do segundo órgão jurisdicional. Assim, uma vez acolhido o recurso interposto contra 0 ato do juiz nacional conrário à $\mathrm{CEDH}$, tal como interpretada pelo TEDH, o mesmo juiz deve, em principio, conformar-se com a sentença do TEDH ${ }^{89}$. Em contrapartida, tratando-se de um tribunal da Comunidade dual näo é parte contratante da $\mathrm{CEDH}$ - um tal conflito de jurisprudência não pode resolver-se da mesma forma.

De resto, no próprio quadro institucional da CEDH, foram já declarados inadmissiveis não só os recursos contra atos imputáveis à Comunidade, como também os recursos contra os atos adotados pelos Estados-Membros em execução do direito comunitário. Num primeiro momento a decisão de inadmissibilidade fundamentou-se na mera constatação de que, por um lado, 
a Comunidade não é parte da CEDH e, por ou- nidade Européia a qual se juntaria, assim, entro lado, os Estados-Membros ao participarem nas decisões do Conselho da Comunidade não exercem a sua jurisdição na acepção do artigo $1^{\circ} \mathrm{da} \mathrm{CEDH}^{90}$. Levada às suas últimas consequências, esta fundamentação equivaleria, paradoxalmente, a admitir que os Estados partes na CEDH podem subtrair-se às obrigações desta decorrentes mediante a simples transferência de competência para uma entidade como a Comunidade Européia. Tal ilação veio, porém a ser afastada por uma decisão de inadmissibilidade de um recurso interposto contra um ato nacional de execução do direito comunitário. A fundamentação aduzida foi a seguinte: a CEDH não proibe as partes contratantes de transferi competências para uma organização internacional; porém, uma tal transferência não pode excluir a responsabilidade das partes pelo exer cício das competências de que se trate; tornase, por conseguinte, necessário que no âmbito da organização internacional em questão os direitos fundamentais sejam protegidos de uma forma à que é garantida no âmbito da $\mathrm{CEDH}$ ora, a Comunidade Européia e, em particular, a jurisprudência do $\mathrm{TJ}$ garantem uma proteção eficaz dos direitos fundamentais relativamente aos poderes de autoridade exercidos pelos respectivos órgãos ${ }^{91}$.

Seja como for, o certo é que nem o TEDH pode fiscalizar regularmente o exercicio dos poderes transferidos pelos Estados-Membros para os órgãos da Comunidade, nem os particulares que se considerem afetados nos seus direitos fundamentais por atos imputáveis à Comunidade podem impugná-los perante as instituições encarregadas de assegurar o respeito doa CEDH. Ora, a Comunidade constitui presentement uma entidade "quase-estadual", dotada de vastos poderes de autoridade suscetiveis de afetar os direitos fundamentais de todos os que se encontram sujeitos à sua jurisdição. Nestas condiçōes a sua plena submissão, em pé de igualdade com os Estados-Membros, à CEDH, tal como a interpreta e aplica em última instância o TEDH, pode contribuir para melhorar significativamente a proteção dos direitos fundamentais de quem se encontre de alguma forma sujeito ao ordenamento comunitário.

É precisamente com este objetivo que surge a proposta de adesão formal à CEDH da Comu- quanto parte contratante aos vinte e oito Estados europeus aderentes, ficando como eles submetida à jurisdição do TEDH e participando igualmente nos órgãos instituidos pela $\mathrm{CEDH}^{92}$. Tal proposta, da autoria da Comissão, remonta a 4 de Abril de 1979, tendo posteriormente sido renovada em 19 de Novembro de 1990 e 26 de Outubro de 1993. O Parlamento Europeu, por seu lado, pronunciou-se igualmente a favor da adesão, por último, através da Resolução de 18

Presentemente encontra-se pendente no $\mathrm{TJ}$ um pedido de parecer apresentado pelo Consetho sobre a compatibilidade com o Tratado de um projeto de acordo de adesão da Comunidade à CEDH. Da resposta do TJ depende, para já, nos termos do artigo $228, n^{\circ} 6$, do Tratado, a concretização da adesão.

\section{NOTAS DE REFERÊNCIA}

1 Cf. os acórdãos de 18 de Junho de 1991, Ellinik Radiophonia Tileorassi AE (ERT), processo C-260/ 89. Coletânea da Jurisprudência do Tribunal de Justiça (a seguir designada por "Colect."), p. I-2925, pontos 41-42, de 4 de Outubro de 1991, Society for the Protection of Unborn Children Ireland (SPUC) processo C-159/90, Colect. p. I-4685, ponto 31, de 24 de Março de 1994, Bostock, processo C-2 92, Colect. p. I-955, ponto 16.

Cf. José Carlos Moitinho de Almeida, "La proteccion de los derechos fundamentales en la jurisprudencia del Tribunal de Justicia de las Comunida-
des Europeas" in Gil C.R. Iglesias e D.J. Liñan Nodes Europeas" in Gil C.R. Iglesias e D.J. Liñan Nores desenvolvimentos sobre 0 conceito de direitos fundamentais ver por ültimo, Peter Häberle "Das Konzept der Grundrechte", Europaisshe Rechtskutur, Baden-Baden, 1994, p. 279.

3 No presente estudo, ter-se-á apenas em conta o Tratado de Roma - que passou a denominar-se Trata to da Comunidade Européia na sequência da ervisão de que foi alvo pelo Tratado da União Européji são de que foi alvo pelo Tratado da União Européia,
assinado em Maastricht em 7 de Fevereiro de 1992 - em cujo âmbito o tema dos direitos fundamen tais assume particular relevância.

4 Para maiores desenvolvimentos, cf. Joseph H.H. Weiler, "Methods of Protection: Towards a Second and Third Generation of Protection" in A. Cassese A. Clapham e J. H.H. Weiler (edit.) Human Rights and the European Community: Methods of Protection,

Sobre este ponto, cf. Antonio Saggio, “A proteçào dos direitos fundamentais na ordem juridica comude Janeiro de 1994. gueras (edits.) El Derecho Comunitario Europeo y su Baden-Baden, 1991, p. 565. nitária", O Sistema Jurisdicional Comunitário e a sua Contribuição para a Integração Européia, Lisboa, 1993 p. 70 .

6 Sobre o tema ver o importante estudo de Albert Bleckmann, "Die Personenverkehrsfreiheit im Recht der EG. Vom Gleichheitssatz zur Verankerung absoluter Grundrechte", Deutsches Verwaltungsblatt, 1986 p. 69; ver também Georg Ress, "A livre ciriculação de pessoas, de serviços e de capitais", Trinta Ano

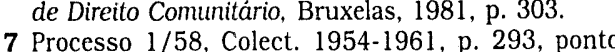
7 Proces

4.a.
8 Neste sentido, cf. Hjalte Rasmussen, On Law and 8 Neste sentido, cf. Hjalte Rasmussen, On Law and 1986, p. 395.

9 Processo 29/69, Colect. 1969-1970 p. 157, ponto 7. Como observa Spyridon Flogaytis, "Droits londamentaux et principes generaux du droit adminis-
tratif dans la jurisprudence de la Cour de justice tratif dans la jurisprudence de la Cour de justice",
Revue européenne de Droit public, 1992, p. 297, fo preciso esperar pelo acórdāo Stauder para integrar preciso esperar pelo acordao Stauder para integra artigo 164 do Tratado; cfr. supra, $\mathrm{n}^{\circ} 2$.

10 Para um elenco dos direitos fundamentais pretorianamente consagrados na ordem juridica comunitária, com referèncias jurisprudenciais ver, entre tantos, Vittorio di Bucci, "Droits fondamentaux" in A. Barav et Ch. Philips (edits.) Dictionnaire juridique des Communautés europeennes, Paris, 1993, p. 412; Frederico Mancini e Vittorio di Bucci, "Le développement des droits fondamentaux en tant que partic du droit communautaire" in A. Clapham (edit.) Co lected Courses of the Academy of European Law, I, 1 Florença, 1990, p. 35; Constantinos N. Kakouris "La jurisprudence de la Cour de justice des Communautés européennes relative aux Droits de T'Homme" in Julia lliopoulos-Strangas (edit.) Grun1991, p. 183.

11 Sobre o processo de constitucionalização dod Tratado, ver J.L. Cruz Vilaça e Nuno Piçarra "Y a-tdes lintes matertllis a la revision des traités inst Droit Européen, 1993, p. 10 e ss.

$12 \mathrm{Cf}$. os acórdāos de 12 de Novembro de 1969, Stauder, supracitado, de 17 de Dezembro de 1970, Internationale Handelsgesellschaft/Einführ - und Vorratsstelle Getreide (processo 11/70, Colect. 19691970, p. 625, ponto 4), de 14 de Maio de 1974, nold/ Comissão (processo 4/73, Colect. 1974 p. 283, ponto 13), de 13 de Dezembro de 1979, Hauer/Land Renânia-Palatinado (processo 44/79, Colect. p. 3727 , ponto 15$)$

$13 \mathrm{Cf}$. especialmente os pontos 3 e 4 acórdão Internationale Handelsgesellschaft, supracitado.

14 Neste sentido, ver por exemplo Joseph H.H. Weile et Nicolas J.S. Lockhart, "Taking Rights Seriously" Seriously: The European Court and its Fundamen-
tal Rights Jurisprudence", Common Market Law Re- view, 1995, p. 598; Giorgio Gaja, “Aspetti problematici della tutela dei diritti fondamentali nell'ordinamento comunitario", Scritti in Onore di Paolo Barile, Pádua, 1990, p. 627; Damaso Ruiz-Jarabo, "Tecnicas juridicas de protección de los derechos humanos en la Comunidad Europea", Revista de Instituciones Europeas, 1990, p. 180

Em todo 0 caso, do artigo $M$ das disposições finais do Tratado da União Européia resulta que nenhua relativo à proteção dos direitos fundamentais no ambito da Comunidade: a este propósito of Deirdre curta "The Constir Union: a Europe of Bits and Pieces", Common Market Law Review, 1993, p. 20, nota 18.

6 Processo 26/62, Colect. 1962-1964, p. 205, 212.

16 Processo 26/62, Colect. 1962-1964, p. 205, 212.

18 Sobre o tema, cf. Mancini, "The Making of a Constitution for Europe", Common Market Law Review, 1989, p. 611; Cruz Vilaça, "Derecho Comunitario Europeo y Derecho Constitucional de los Estados Miembros de la Comunidad", Memoria del Tribunal de Justicia del Acuerdo de Cartagena, 1991, p. 119; Weiler, "Human Rights and the European Community", cit. p. 581, para quem a mudança de jurisprudência do acorda der é "uma conseqüência inevitável dos acórdãos Van Gend \& Loos, Costa/ENEL e sua descendência".

Lembre-se que, em coerência com o sistema descrito, são particularmente restritivas as condições em que os particulares podem impugnar diretamente perante o $\mathrm{TJ}$, nos termos do artigo 173 do os atos normativos da Comunidade

Cr. F. Mancini e D. Keeling, "From CILFIT to ERT the Constitutional Challenge facing the European

$1 \mathrm{Cf}$. Entscheidungen del Bundesverfassungsgerichts (BVerfGE), 37, p. 271 e ss.

2 Ver 0 acórdāo de 22 de Outubro de 1986, BVerfGE, 73 , p. 339 , também ele proferido na sequeência de uma decisão prejudicial do TJ que não se pronunciou pela invalidade dos regulamentos comunitáriWünsche/Alemanha, processo $126 / 81$, Colect. p.

1479.
23 Ver o despacho de 12 de Maio de 1989, Neue Juristische Wochenschrift, 1990, p. 974

Ver 0 acórdão de 12 de Outubro de 1993, Europäische Grundrechte, 1993, p. 429, 435

25 Ver 0 acórdão de 27 de Dezembro de 1973, Giurisprudenza Costituzionale, 1973, p. 2401

26 Ver 0 acórdão de 21 de Abril de 1989, Rivista Italiana di Diritto Pubblico Communitario, 1991, p. 138; 0 acórdao do $\mathrm{T}$ que lhe deu origem data de 22 de Maio de 1985, Fragd/Amministrazione delle Finanze dello Stato, processo 33/84, Colect. p. 1605.

Neste sentido, Enzo Cannizzaro, "Tutela dei diritti 
costituzionali secondo le corti costituzionali italiana e tedesca", Rivista di Dintlo Internazionalle, 1990, p. 379 .

28 Sobre a transformação do artigo 177, cf. Mancini e Keeling, "From CILFIT to ERT", cit., especialmente p. 8-9; para maiores desenvolvimentos, ver J.H.H. Weiler, "Journey to an Unknown Destination: a Retrospective and Prospective of the European Court of Justice in the Arena of Political Integration" in
Journal of Common Market Studies, 1993, p. 417.

29 Journal of Common Market Studies, 1993,

30 Processos apensos 60 e $61 / 84$, Colect. p. 2605. No entanto, já anteriormente, nos processos prejudiciais Royer $48 / 75$. Colect $p .497$ e Wastejulicmann, 118/75, Colect p. 1185, se havia suscitado expressamente a queustão da compatibilidade expressamente a queustao da compatibilidade de só com as disposiçoses do Tratado relativas à livre circulação das pessoas mos também com determinadas disposiçōes da CEDH. O TJ, porém, ignorou as questōes relacionadas com a CEDH; cf. acórdãos de 8 de Abril de 1975, proferido no primeiro processo, e de 7 de Julho de 1976, proferido no segundo. Neste último, porém, o advogado-geral defendeu a competência do TJ na matéria com uma fun1 Ponto 26.

32 Esta posição foi defendida designadamente pelo advogado-geral Francesco Capotorti, em conclusōes apresentadas no processo 149/77, Defrenne/Sabena, Colect. 1978, p. 1386. Segundo o autor, "as relaçōes juridicas deixadas à competência do legislador nacional devem entender-se como sujeitas a principio constitucional dos direttos do homem, em vigor no Estado pelo qual uma tal relaçáo é regula não tiverem sido substituidas por uma regulamentação comunitária diretamente aplicável". $33 \mathrm{Cf}$. as conclusões do advogado-geral Gordon Slynn, p. 2ur rayäo cm afirmar que as derrogacóes ao artio 36 e que o alcance das "exigências imperativas", cujo efeito é excluir una determinada medida do âmbito de aplicação do artigo 30, devem ser interpretado à luz da Convenção [Rutili, ver as conclusōes do advogado-geral Warner no processo 34/79 Regina/ Henn e Derby (Colect. 1979, p. 3795 , na página $3821)]^{\circ}$

34 Para alèm dos três fundamentos derrogatörios comuns, 0 artigo 36 enumera ainda a moralidade pûblica, a proteção da vida das pessoas e animais ou a preservação das plantas, a proteção do patrimồnio nacional de valor artistico, historico ou arqueológico e a proteção da propriedade industrial e comercia

35 Sobre as exigências imperativas de interesse geral ver o acórdão de 20 de Fevereiro de 1979, Rewe/ Bundesmonopolverwaltung für Branntwein, mais
conhecido por Cassis de Dijon, processo $120 / 87$ conhecido por Cassis de Dijon, processo $120 / 87$,
Colect. p. 649 , ponto 8; para um enunciado das exigências imperativas de interesse geral já reconhecidas pelo TJ, ver, por exemplo de Julho de 1991, Con . I-4069, pontos 17 e 18 Neste sentido, ver por último Weiler e Lockhart, op cit., p. 75 .

37 Processo 36/75, Colect. p. 415

38 Pontos 26 e 27

Cf. a parte dispositiva do acórdão, $n^{\circ} 2$, primeiro parágrafo.

41 Sobre 0 acórdão Rutili e suas implicações, ver com Sobre o acordaa o Rutili e suas implicaçoes, ver com
desenvolvimento Denys Simon, "Ordre public et libertés publiques dans les Communautés européennes. À propos de l'arrêt Rutili", Revue du Marché Commun, 1976, p, 214. O autor colocava ai uma
questão de grande pertinência, adiante examinada, questão de grande pertinência, adiante examinada, e que formulava nos seguintes termos: tendo em da livre circulação de trabalhadores (artigo 48) e da igualdade (artigo $7^{\circ}$ ) para defender os direitos dos cidadãos da Comunidade, pode questionar-se a utilidade da argumentação desenvolvida pelo acórdão em questão a propósito das obrigaçōes decorrentes da CEDH (p. 218).

42 Colect. 1976, p. 1207; na doutrina, contemporaneamente, ver Michel Waelbroeck, "La protection des droits fondamentaux à l'ègard des Etats membre dans le cadre communaulare, Mélanges Fernand Dehousse, vol. 2, p. 323

43 Tratava-se da Diretiva do Conselho no 64/221, de 25 de Fevereiro de 1964, relativa à coordenação das medidas especiais aplicáveis aos estrangeiros em matéria de deslocaçáo e de estadia justícadas por de pide (J0 1964, p. 850).

44 Pontos 21 a 24

f. os acórdãos citados na nota 12

Nas conclusões, o advogado-geral, em consonância cia do sua posica de principio quanto à competênvocados no sentido da violacão pela lei francesa incausa, do artigo 10 da CEDH, tendo considerado não se estar em presença de uma tal violaçãa no caso concreto.

47 Sobre 0 acórdão Cinéthèque ver, em sentidos diferentes, Weiler, "The European Court at a Crossroads: Community Human Rights and Member State Action", Du droit international au droit de l'integration. Liber amicorum Pierre Pescatore, Baden-Baden, 1987 p. 821; Andrew Clapham, Human Rights and the European Community: A Critical Overview, Baden-Baden, 1991, p. 37-45; Mancini e Di Bucci, op. cit., p. 44-46.

48 Processo 12/86, Colect. p. 3719.

49 Processo 222/84, Colect. p. 1651

50 Processos apensos 201 e 202/85, Colect. p. 3477

Processo 5/88, Colect. p. 2609.

is posição adotada pelo conselho de associação ape- nas proibe novas restriçōes no que toca às condicooes de acesso ao emprego.

53 Para uma do acordao Demirel, ver J.H.H. Weiler, "Thou Shal Not Oppress a Stranger: On the Judicial Protection of the Human Rights of Non-EC Nationals - A Cntique , European Journal of International Law, 1992 especialmente p. 79-82; cf. tambem as observaçoes de Ingrid Persaud, Where do we go from here? Fundamental Rights in the Post-Maastricht Legal Order, publicaçoes do Europa-Institut da Unve

54 Pantos 17 e 18 .

55 Pontos 8 e 9 .

$56 \mathrm{Cf}$ especialmente os pontos 19 e 22 .

57 Ver a decisão do tribunal alemão a quo proferida em consequência do acórdão Wachauf in Common $\mathrm{Ma}$ rket Law Reports, 1990, p. 289

58 Salientando este aspecto, John Temple Lang, "The Sphere in which Member States are obliged to com-

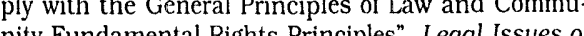
European Integration, 1991/2, p. 25.

59 Segundo um estudo efetuado pelo Senado francês em 1988 e citado apud Mancini, "Democracy and the European Court of Justice", Modern Law Review. 1993, p. 17, 15\% das medidas que afetam as atividades economicas dos particulares no espaco comunitário têm origem em Bruxelas; outros 30\% são adotados pelas autoridades nacionais em execução de atos adotados pelo Conselho e pela Comissão.

60 Sobre este ponto cf. Weiler e Lockhart, op. cit., p. 622. Segundo os autores, em muitos casos, a propria noção de Estado-Membro como ator homogêneo e monolitico deixa de fazer sentido no contexto da integração européia.

61 Ponto 16; nesta parte, o TJ não seguiu as conclusōes do advogado-geral Claus Gulmann, proferidas no processo em análise. Para o advogado geral $\left(\mathrm{Co}_{0}\right.$ lect. 1994, p. I-972), "o fato de um problema juridico se pôr na sequencia da adoção de regras comunitarias náo implica por si so, em nossa opiniāo, que a soluçáa dada aoa problem elas autopilades tos fundamentais aplicáveis em direito comunitá-

2 Cf. os pontos 18 a 24 do acór

ponto 19 do acordão Wachauf.

Bostock, ver Weiler e Lockhart, op. cit. p. 605-617.

Cf. supra nota 41

65 Processo 352/85, Colect. p. 2085.

66 Ver as conclusōes do advogado-geral Federico Mancini, Colect. 1988, p. 2084.

67 Cr. pontos 26-27, 32-33 e 40-41.

68 Processo C-326/88, Colect. p. I-2911; cf. as conclusões do advogado-geral Walter van Gerven, p. I2919, pontos 11-15.
69 Processo C-168/91, Colect. p. I-1191, pontos 12 e 15-17; cf. as conclusōes do advogado-geral Francis Jacobs, p. I-1198, pontos 31 e segs.

70 Neste sentido, Clapham, op. cit., p. 41 . Colect. 1991, p. I-2949.

72 Pontos 23 a 26

$3 \mathrm{Em}$ sentido critico, considerando, neste contexto, o "teste do respeito pelos direitos fundamentais" como mais uma manifestação de ativismo judiciário próComunidade do TJ, Jason Coppel e Aidan O'Neill, "The European Court of Justice: Taking Rights Seriously?", Common Market Law Review, 1992, p. 669. Os autores entendem que, para o TJ, os direitos fundamentais mais nao constituem do que uma bros têm que vencer para poderem ser considerados compativeis com o direito comunitário.

74 Procss C-159/90, Colect p. I-4685.

75 Pontos 24 a 27

76 Tanto o TJ como o advogado-geral Walter van Gerven entenderam que a interrupção médica de gravidez, realizada em conformidade com o direito do Estado-Membro em que é efetuada, constitui um serviço na acepção do artigo 60 do Tratado; cf. o ponto 21 do acórdão com a p. I-4731 das conclusões.

77 Note-se a grande semelhança, no que toca ao método seguido, entre as conclusões apresentadas no processo SPUC e as apresentadas no processo $\mathrm{Ci}$ nèthèque.

78 Cf. em especial a p. I-4728 das conclusōes.

Sobre o acórdão SPUC, ver o comentário de Deirdre Curtin in Common Market Law Review, 1992, p. 585; ver também Laurence Idot, "A propos de l'interruption volontaire de grossesse: premier bilan de la jurisprudence de la Cour relative à la libre prestation de services en 1991 . Ed 1991, p. 4.

Ver 268 U.S. 1925 p. 625-673.

(1) este tema cf. Weiler, "The European Court at cit., p. $837-839$

Para maiores desenvolvimentos a este respeito, cf. P. 827; Caja, op cit, p. 632. Temple Lang op cit. p. 30 .

83 Neste sentido, ver por último Francis Jacobs, Human Rights in the European Union publicacooses do Durham European Law Institute, 1994, p. 7.

84 Cf: Weiler e Lockhart, op. cit., p. 591 e 621.

85 Cf. supra, Capitulo II, B e Capitulo III, A

86 No entanto, a diferença entre os diversos regimes relativos aos direitos fundamentais está menos no elenco dos direitos protegidos do que no modo como é feita a ponderação entre cada um deles e o interesse geral da sociedade.

87 De resto, na decisão citada na nota 23 , o Bundesverfassungsgericht pronunciou-se expressamente pela plena vinculação ao catálogo constitucional de 
direitos fundamentais do legislador nacional no ato de transposição de uma diretiva.

88 Cf. o acórdão do TJ de 21 de Setembro de 1989 Hoechst/Comissão, processos apensos 46/87 $227 / 88$, Colect. p. 2859 , ponto 18 , com o acórdão do TEDH de 16 de Fevereiro de 1992, Niemitz, Série A, n $251-\mathrm{B}$, pontos 29 e 31 .

89 Segundo o artigo 50 da CEDH, "se a decisão do Tribunal declarar que uma decisão tomada ou uma providencia ordenada por uma autoridade judicia ou qualquer outra autoridade de uma Parte Contratante se encontra, integral ou parcialmente, en oposição a obrigaçoes que derivam da presente Convenção, e se o direito interno da Parte só por forma inperferta permalr rencelar as corequencias da- concederá à parte lesada, se for procedente a sua causa, uma reparacão razó́vel.

90 Ver por exemplo a decisāo da Comissão Europé dos Direitos do Homem lórgão encarregado de "filtrar" os recursos interpostos para o TEDH) de 8 de Maio de 1985, Dufay/bélgica e Comunidade Européia, Common Market Law Reports, 1987, p. 57.

$91 \mathrm{Cf}$. a decisão da Comissão Européia dos Direitos do Homem de 9 de Fevereiro de 1990, M. \& Co./República Federal da Alemanha, Décisions et Rapports, vol. 64, p. 138

92 Sobre o tema ver a sintese particularmente incisiva de Jörg Pipkorn, "La Communauté européenne e la Convention europenne des drolls de lhomme" w Trimestrielle des Droits de l'Homme, 1993,

\section{As Principais Teorias de Direito Penal, Seus Proponentes e Seu Desenvolvimento na Alemanha}

PETER WALTER ASHTON

Professor Titular de Direito Comercial e Mercado de Capitais nas Faculdades de Direito da UFRGS e da PUC/RS

\section{INTRODUÇÃO}

\section{Razão e Fim/Objetivo da Pena}

Porque deve ser punido o autor delinqüente? $\mathrm{O}$ que se pretende obter/conseguir com a aplicação da pena?

0 problema assim colocado pelas perguntas acima, que envolve a explicação e justificação da pena é antigo. Uma resposta que seja aceita por todos até hoje ainda não foi encontrada.

Todas as tentativas de solução da questão (vexata questio) partem de três proposições:

Segundo a teoria absoluta a pena é a retaliação e a expiação.

Retaliação da sociedade imposta pelo estado e expiação do ato delito praticado pelo delinqüente. A teoria absoluta não se preocupa em ser meio de combate à criminalidade. Vale o principio: Punitur, Quia Peccatum Est

Pune-se e deve se punir porque foi cometido um delito.

O representante mais famoso desta teoria é Immanuel Kant. E conhecido o famoso exemplo por ele posto: Se a sociedade civil resolver auto dissolver-se, com a concordância de todos os seus cidadãos, mesmo assim, caso esta sociedade habitar uma ilha e resolver abandoná-la espalhando-se pelo mundo, o último assassino condenado e preso teria que ser executado, antes do abandono final da ilha pelo último membro do povo. Isto deverá assim acontecer para que cada um receba a punição equivalente aos seus atos e a divida de sangue não permaneça vinculada ao povo. Segundo Kant (1724-1804) as leis penais obrigam todo homem não diminuir ou lesionar a liberdade externa do co-cidadão. Destarte as leis penais formam ou arvo- ram-se em imperativos categóricos, que devem ser obedecidos sem questionamento. 1

As teorias relativas preocupam-se com os fins e objetivos da pena. Para caracterizar a preocupação central destas teorias relativas é importante a formulação dada por Seneca (filósofo romano, educador de Nero - 4aC-64-dC).

Nemo prudens punit, quia peccatum est, sed ne peccetur

Ninguém que é prudente, pune porque foi cometido um delito, mas pune (sim) para que no futuro não sejam cometidos delitos.

Portanto a preocupação central destas teorias é envidar esforços para evitar o cometimento de futuros delitos, a prevenção de delitos. Dependendo sobre quem a aplicação da pena deve exercer influência e efeitos há duas formas de prevenção:

a) o fim e objetivo da aplicação da pena ao delinqüente pode ser visto no efeito que a aplicação desta pena tem sobre outros, terceiros. que poderão ser, desta forma, atemorizados para não delinqüir. É a teoria da prevenção geral2 20 representante mais famoso desta teoria foi Paul Johann Anselm von Feuerbach, que reforçou a sua teoria penal com a idéia da coação psicológica do possivel e futuro delinqüente em potencial. Sendo o delito um ato dos sentidos, deve ser combatido, negativado por fortes imagens negativas da pena. 0 potencial delinqüente que tiver tendências de delinqüir deve ser impedido psicologicamente de atuar.

b) A teoria da prevenção especial moderna (para não confundir com as teorias de prevencão especial antigas de Christoph Carl Stuebel (1764-1827) e Karl Ludwig Wilhelm von Grolmann (1775-1829), preocupa-se com o delin- 